This is the peer reviewed version of the following article: Grabowski, R.C., Surian, N., Gurnell, A.M. Characterising geomorphological change to support sustainable river restoration and management, WIREs Water 2014. doi: 10.1002/wat2.1037 which has been published in final form at doi: 10.1002/wat2.1037. This article may be used for non-commercial purposes in accordance with Wiley Terms and Conditions for Self-Archiving

\title{
Characterising geomorphological change to support sustainable river restoration and management
}

Robert C. Grabowski*, Queen Mary, University of London, UK; Cranfield Water Science Institute, Cranfield University, UK; r.c.grabowski@gmail.com

Nicola Surian, University of Padova, Italy

Angela M. Gurnell, Queen Mary University of London, UK

\begin{abstract}
The hydrology ad geomorphology of most rivers has been fundamentally altered through a long history of human interventions including modification of river channels, floodplains and wider changes in the landscape that affect water and sediment delivery to the river. Resultant alterations in fluvial forms and processes have negatively impacted river ecology via the loss of physical habitat, disruption to the longitudinal continuity of the river and lateral disconnection between aquatic, wetland and terrestrial ecosystems. Through a characterisation of geomorphological change, it is possible to peel back the layers of time to investigate how and why a river has changed. Process rates can be assessed; the historical condition of rivers can be determined; the trajectories of past changes can be reconstructed; and the role of specific human interventions in these geomorphological changes can be assessed. To achieve this, hydrological, geomorphological and riparian vegetation characteristics are investigated within a hierarchy of spatial scales using a range of data sources. A temporal analysis of fluvial geomorphology supports process-based management that targets underlying problems. In this way, effective, sustainable management and restoration solutions can be developed that recognise the underlying drivers of geomorphological change, the constraints imposed on current fluvial processes, and the possible evolutionary trajectories and timelines of change under different future management scenarios. Catchment / river basin planning, natural flood risk management, the identification and appraisal of pressures, and the assessment of restoration needs and objectives would all benefit from a thorough temporal analysis of fluvial geomorphology.
\end{abstract}

\section{INTRODUCTION}

In many countries, regulatory objectives now require rivers to be managed in a holistic manner that balances human use and modification with the preservation and improvement of aquatic and riparian ecosystems. Implicit in these objectives is the acknowledgement that the hydrology and geomorphology of rivers has been fundamentally altered through a long history of direct intervention to river form and water flow as well as wider changes in the landscape that impact water and sediment delivery to the river ${ }^{1,2}$. These alterations in fluvial forms and processes have negatively impacted river ecology through the loss of physical habitat, disruption to the longitudinal continuity of the river and a disconnection between aquatic, wetland and terrestrial ecosystems $\mathrm{s}^{3,4}$. However, the numerous demands on rivers (e.g. freshwater supply, navigation, flood protection) and 
dwindling financial resources to maintain current infrastructure and maintenance operations have placed an emphasis on the identification of effective management and restoration approaches that yield sustainable solutions ${ }^{5,6}$. Working with the river's natural hydrological and geomorphological processes, as opposed to imposing form and behaviour, offers the best opportunity to do so ${ }^{4,7,8}$. A process-based management approach requires an understanding of not only the current geomorphological condition a river, but also how this has changed over time. Whilst from an ecological perspective, river restoration and broader management should target the measures and river reaches that would provide the greatest and most cost-effective impact in terms of reinstating and sustaining natural processes, it is critical that direct and indirect human interventions are factored into such an approach. Furthermore, although this paper emphasises understanding of processes and their direct relevance to restoration, this is only a small part of the many factors that are incorporated into river restoration in practice. Thus good science can contribute to the design of effective and sustainable restoration and management schemes, but the location(s), detailed design, and financing of such schemes are often more dependent upon a host of human-related issues that are beyond the scope of this review ${ }^{9}$.

Rivers change over time. This is an inherent property of rivers and floodplains, and is driven by forces operating within the channel (i.e. intrinsic) and as a result of changes in the wider catchment (i.e. extrinsic). Temporal changes in fluvial geomorphology can be expressed in a river in many different ways: the spatial location of the channel (e.g. lateral migration and avulsions); riverbed and floodplain levels (e.g. channel incision and floodplain sedimentation); channel planform and dimensions; bed sediment characteristics; and the frequency and diversity of geomorphic units in the channel and floodplain. Some of these changes may be natural for the river type, whilst others are induced by changes that have occurred elsewhere in the catchment. By recognising that rivers are dynamic, a temporal analysis of fluvial geomorphology can support river management and restoration by providing information on:

- Rates of geomorphological, hydrological and ecological processes (e.g. water flow, sediment transport, riparian and aquatic plant growth and succession),

- The previous condition of the catchment, floodplain and channel,

- Rates and trajectories of past change in channel and floodplain characteristics,

- Identification of human pressures and how they have changed over time,

- Channel response to past natural disturbances and human pressure.

Whilst there is a growing recognition of the role of process-based management and restoration of rivers (e.g. the concept of 'Making space for water' promoted by the Department for Environment Food and Rural Affairs, in the UK), the identification, planning and implementation of individual measures is often the best outcome of the complex interaction between various legal frameworks, regulatory drivers, policy initiatives and stakeholder engagement which is compounded by the opportunistic nature of restoration projects (i.e. a willing landowner). Frequently, the result is piecemeal management that treats the symptoms of alterations to geomorphological processes rather than the causes, with the consequence that measures may not meet their intended objectives. The outcomes of a thorough temporal analysis provide managers with the information needed to develop a holistic understanding of their rivers and floodplains. It allows them to identify the nature, magnitude and underlying causes of geomorphological change in a reach, the human constraints imposed on future restoration and management, and the possible evolutionary trajectories and timelines of change under different future management scenarios. This information can be used to develop effective and sustainable solutions with process-based objectives, regardless 
of whether they are integrated catchment-scale measures to tackle multiple pressures and improve ecological status, or reach-scale projects to improve physical stream habitat or local amenity.

The aim of this review is to provide guidelines and suggestions for the temporal analysis of geomorphological change in rivers which can inform process-based river management and restoration. The article is structured around a spatial hierarchical framework that nests the reach and its distinctive geomorphic forms and processes into a wider spatial context. A brief outline of the spatial scales is given, followed by an introduction to the types of approaches used in a temporal analysis and the timescales over which they are relevant. Then at each spatial scale, characteristics are identified that control critical fluvial processes or are indicative of channel adjustment, alteration or artificiality. Recommendations are provided on the approaches for gaining information on each characteristic, the range of data that can be collected using those approaches, suitable analytical techniques and methods to assess data accuracy. Finally, the role of a temporal analysis of geomorphology in the development of sustainable river restoration and management strategies is discussed.

\section{SPATIAL AND TEMPORAL SCALES OF ANALYSIS}

The geomorphological character of river reaches depends not only upon interventions and processes within the reach but also within the upstream (and sometimes the downstream) catchment. In addition, the character of river reaches responds in a delayed way to processes and interventions within the catchment. As a result, understanding geomorphology at the reach scale requires an understanding of current and past processes and interventions at larger spatial scales. Without such a multi-scale understanding, management strategies are not fully informed and may not provide sustainable solutions.

Spatial hierarchical frameworks have been proposed in many forms in the literature, each developed with a particular application or set of applications in mind ${ }^{10-17}$. Addition of a formal temporal analysis to such frameworks is rare, although Ref 15 provides an excellent description of how this may be achieved. Nevertheless, many researchers acknowledge space and timescales over which processes may be influential and forms may persist ${ }^{8,10,13,16}$; while others consider scenarios of process dynamics and change ${ }^{11,12}$. This article complements these existing frameworks by providing guidance on the types of characteristics that should be investigated, the various data sources that can be assembled to investigate each characteristic, and data analysis techniques that can be used to support a scientifically-rigorous interpretation of temporal change.

\section{Spatial scales of analysis}

For the present application, a hierarchy composed of four levels of spatial units is used, which is based on and coherent with earlier delineations ${ }^{10,11,15}$. Hydrological, geomorphological and riparian vegetation properties are investigated within this hierarchy to develop a comprehensive picture of geomorphological process-form interactions and their changes over time (Figure 1; Table 1).

The catchment is an area of land that is drained by a river and its tributaries, and, for the purposes of this approach, can be delineated based on the topographic divide (watershed).

Landscape units, i.e. physiographic region / province, are portions of the catchment with similar geomorphological characteristics. The catchment is divided into landscape units that are broadly consistent in terms of their topography, geology and land cover, as these factors determine the 
hydrological responsiveness of a catchment and the sources and delivery pathways of sediment to the river system.

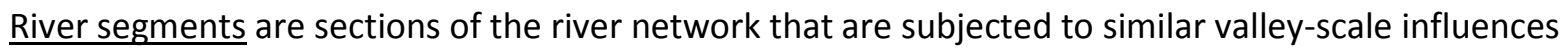
and flow energy conditions. Delineation is based on major changes in valley gradient, major tributary confluences, and valley confinement.

Geomorphologically speaking, a reach is a section of river along which boundary conditions are sufficiently uniform that the river maintains a near consistent set of process-form interactions, resulting in characteristic planform patterns and landforms in the channel and floodplain, such as river meanders, gravel bars and oxbow lakes.

The reach is arguably the most important scale. It is the key spatial scale at which the mosaic of features found within river channels and floodplains (i) responds to the cascade of influences from larger spatial scales and (ii) is influenced by interactions and feedbacks between geomorphic and hydraulic units and smaller elements such as plants, large wood and sediment particles within the reach. The reach is also the scale at which people view and interact with a river, and the scale at which most management and restoration work is directed.

\section{Approaches and timescales of analysis}

A diverse array of techniques can be applied to investigate temporal changes in geomorphological forms and processes from the catchment down to the reach scale. These techniques can be broadly categorised according to the disciplines within which they have been developed, the data sources they utilise, and the temporal scale at which they can be applied (Table 2; Figure 2). For the present review, techniques are divided into 4 major approaches: field survey, remote sensing, historical, and palaeo approaches. Table 2 lists the methods and data sources included within each approach, the timescales over which they are typically applied, and their strengths and weakness for the characterisation of geomorphological change.

The choice of approach for an analysis of temporal change is dependent on the data sources that are available for an area, the history of pressures in the catchment, and the responsiveness of the river to pressures. Some data sources are preferred, typically those that are scientifically-derived, unbiased and are supported by metadata detailing methods and uncertainties / errors. However alternative data sources can be used when and where the preferred data are unavailable, but this may impact on the level of detail or confidence of the resulting interpretation. A river situated in a region with a long history of human modifications may require a longer timescale of analysis if causal linkages are to be identified between pressures and channel change. Likewise, a river that responds slowly to external forces (e.g. a lowland, low energy river with cohesive banks) may require a longer timescale of analysis to fully capture the trajectory of change that is occurring.

Accuracy, error and uncertainty are discussed in more detail in a later section, but it is important to bear in mind that the reliability of data to faithfully represent geomorphological forms, processes and events varies considerably within and between data sources. All data sources should be checked to determine the original purpose of the data, the person or authority that recorded the data, when it was recorded and subsequently published, the methods or instruments used, and reported levels of accuracy (spatial, temporal, attribute) to determine its suitability for a particular analysis.

\section{Integrating data from different sources and scales}


One of the main challenges of a temporal analysis is to integrate data from a wide range of sources with varying levels of reliability in order to detect genuine changes in the catchment, floodplain and river channel. This is where a geographical information system (GIS) becomes particularly useful. Once the datasets are correctly loaded into a GIS, they can be queried and analysed using a veritable toolbox of techniques.

A chronology to visualise the changes that have occurred in the catchment, riparian corridor and channel over time provides a useful way of synthesising changes and their potential causes (Figure 3 )

18,19 . The chronology pulls together information on the characteristics that influence geomorphological processes and those that respond to changes in those processes. This allows changes in characteristics to be tracked over time (e.g. land cover, riparian vegetation, human interventions, river flow regime including major flood or drought events, channel planform pattern, channel width, etc.) and also allows the causal linkages between them to be explored.

\section{CHARACTERISTICS INVESTIGATED AT EACH SPATIAL SCALE}

This section outlines what characteristics should be examined at each spatial scale, which approaches and data sources are recommended to investigate them, and how they can be analysed and interpreted to quantify temporal change. Whilst we identify preferred approaches and data sources, we recognise that these may not be available for every location or time period being investigated. Therefore, a range of alternative data sources is presented for all characteristics to maximise the likelihood of finding information to support the characterisation. Finally, some discussion of the limitations of data sources is presented, but readers are referred to Table 2 for a general overview of the timescales of analysis, strengths and weakness of different approaches.

\section{Catchment / Landscape unit scale}

The geomorphological characteristics investigated at the catchment and landscape unit scales relate to the underlying drivers of river change: water and sediment. This section explores temporal variations in land cover/land use, land topography, and precipitation and groundwater. Some important characteristics, most notably geology, are not included in this analysis, as they do not change substantially over the timescales under consideration. To facilitate presentation, the catchment and landscape unit spatial scales are combined here because characteristics and key processes that are subject to temporal change are similar at both scales (Table 1); however a higher level of detail would be expected for characteristics evaluated at the landscape unit rather than catchment scale.

\section{Land cover / Land use}

Land cover / land use (LCLU) is a significant controlling factor on catchment hydrology and sediment production. Large-scale changes in LCLU can alter surface run-off and sediment production ${ }^{20,21}$ and in severe cases even influence regional climate and precipitation patterns ${ }^{22}$. An analysis of temporal changes in LCLU relies principally on remote sensing and historical approaches, utilising satellite imagery, aerial photography and land/tax surveys.

Satellite imagery is now the most commonly used data source for quantifying changes in LCLU over time at the catchment and landscape unit scales. A large range of datasets is currently available for this purpose, varying in the type of sensor used, spectral resolution and range, and the spatial 
resolution of the resulting data, and their applicability depends on the spatial scale and level of detailed needed (Table 3$)^{23,24}$. Aerial photography can be used to extend the temporal analysis of LCLU further back in time, in many countries to at least the mid- $20^{\text {th }}$ century. Other types of data from airborne sensors (e.g. LiDAR - light detecting and ranging, and hyperspectral) can be used to investigate land cover but the high spatial resolution of the data and the correspondingly low spatial coverage make them more suited to characterisation at the segment scale.

Classification of LCLU from satellite data and aerial photographs can be done manually based on image characteristics (e.g. tone, colour, texture, shape size, context), but is now more commonly achieved using image analysis software and semi-automated (i.e. supervised) or automated pixelbased or object oriented approaches ${ }^{25,26}$. Temporal change can be represented simply with catchment/landscape unit summaries of the areal cover of the land cover types or using a spatiallyexplicit approach that detects change in the attributes of individual pixels. However caution must be exercised, particularly in relation to the latter option, to minimise errors associated with the position or classification of pixels. Many countries or regions have their own land survey data sets, often based on classification of satellite imagery, which are invaluable to LCLU change analysis and have the added benefit of harmonised LCLU classes (e.g. Corine Land Cover data for Europe ${ }^{27}$ ).

Finally, some countries have long histories of detailed land and tax surveying (e.g. cadastral surveys) that can provide an excellent source of information for the analysis of LCLU. Recent work from Germany ${ }^{28}$ and Sweden ${ }^{29,30}$ are good examples of this approach. The records should be checked prior to use to ensure they are spatially complete for the study region, and that LCLU classes are harmonised over time. Where maps were produced as a part of the land / tax surveying process, they were typically at a large-scale and can often be analysed quantitatively in a GIS, following standard processing and georeferencing steps. For example, cadastral maps date back to the $17^{\text {th }}$ century in Sweden and have been used to document transitions in LCLU over time ${ }^{29}$. Where records are in written format, additional map data, such as parcel locations on a more recent cadastral map, are needed to conduct a spatial analysis of change in a GIS.

\section{Land topography (Tectonics, seismic activity and mass movements)}

Changes in land topography over time will impact on both catchment hydrology and sediment production. However, over the timescales of interest to river restoration and management, they are primarily linked to changes in sediment production ${ }^{31}$. Tectonic movement, seismic activity and mass movements triggered by a variety of processes (land cover change, climate variation, deglaciation, etc.) are major producers of coarse and fine sediment that can be delivered to the river channel. In this section, approaches are presented to assess changes in sediment production over time across the catchment or landscape units. The delivery of sediment to the river channel (i.e. hillslopechannel connectivity or coupling) is addressed at the segment scale and sediment transport at the reach scale.

Remote sensing is the preferred approach to assess changes in land topography and sediment production over time at the catchment and landscape unit scales, but historical maps and geomorphological surveys supported by stratigraphic and sedimentological data can help to lengthen the timescale of analysis and verify results from remote sensing.

The identification and quantification of mass movements has traditionally involved geomorphological field mapping and the manual interpretation of aerial photographs ${ }^{32}$. Whilst these are valuable and time-tested methods, other remotely-sensed datasets have the potential to reduce analytical cost and time, improve feature identification, and extend spatial and temporal coverage ${ }^{33,34}$. For example, recent studies have highlighted the possibility of automatic or semi- 
automatic extraction of mass movement features using high resolution LiDAR DEMs ${ }^{35}{ }^{36}$. Likewise, the volumetric analysis of sediment mobilised during mass movements can now be easily calculated using remotely-sensed data; a DEM of Difference (DoD) can be produced by comparing DEMs of the landscape prior to and following the event ${ }^{37}$. Whilst many DEMs are now freely available online (e.g. SRTM, ASTER-G-DEM), the high spatial resolution of laser-derived DEMS (LiDAR and Terrestrial Laser Scanning - TLS) has expanded the types of processes that can be investigated and has markedly increased the precision of volumetric measurements. Whilst only large mass movement events could have been realistically quantified in the past, aerial LiDAR and terrestrial laser scanning can resolve small changes in landscapes that yield detailed information on coarse and fine sediment production 38.

Where they exist, historical topographic and landslide inventory maps can help to identify the location and extent of landslides in a region. An individual landslide map can indicate the level of landslide activity, but maps from different periods in time allow the calculation of landslide frequency and, if elevation is included on the maps, a rough estimation of sediment produced ${ }^{34,39}$. Documentary and photographic evidence can be used to support geomorphological and stratigraphic interpretations ${ }^{40}$. Landslide susceptibility datasets derived from an analysis of climate, slope, lithology and land cover are also excellent resources to explore the likelihood of landslide activity and any spatial variations within a catchment (e.g. European Landslide Susceptibility Map, Joint Research Centre, European Commission) ${ }^{41}$.

To lengthen the timeframe of the temporal analysis, palaeo-seismic and palaeo-landslide activity can be estimated from topographic, stratigraphic and sedimentological evidence ${ }^{32,42,43}$. For example, palaeo-landslide work based on stratigraphy and radiocarbon dating has demonstrated links between landslide frequency and climate change ${ }^{44}$ that are related to glacial erosion and debutressing following glacial retreat ${ }^{45}$, anthropogenic land cover changes ${ }^{40,46}$ and fluctuations in temperature and the timing, frequency and magnitude of rainfall ${ }^{47}$.

\section{Precipitation and groundwater}

Water drives rivers. Thus data on precipitation, surface hydrology and groundwater are essential to studies of temporal change in geomorphology. The primary source of information is hydrological monitoring records, which are the focus of this short section, though remote-sensing is increasingly being used to characterise surface hydrology and detect change over time ${ }^{48}$.

Hydrological monitoring records are crucial to the investigation of temporal changes in precipitation or groundwater levels. A simple analysis of trends in average, maximum and minimum annual and monthly precipitation or historical intensity-duration-frequency analyses can be extracted from precipitation gauge records to examine general changes in the input of water to the catchment ${ }^{49,50}$. Similarly, spatial and temporal variations in groundwater levels from monitored boreholes can also be investigated ${ }^{51}$. Because of the complex patterns in time series data as well as the interactions between global climate oscillations and precipitation and groundwater levels, time series data may be better analysed using a standardised procedure, such as the Standardised Precipitation Index (SPI) ${ }^{52}$ or Standardised Groundwater level Index (SGI) ${ }^{53}$ that were designed to identify periods of drought, or they can be investigated using non-stationary approaches like Fourier and wavelet analysis ${ }^{54}$. Where borehole or piezometer data are unavailable, information on groundwater can be obtained from age dating, chemical proxies or various hydrogeophysical techniques (e.g. electrical / electromagnetic methods or land-based gravity surveying) ${ }^{55}$. If there is evidence of significant changes in climate, land use or groundwater levels and the necessary data are available, a water budget can be assembled from current and historical data to explore changes in the amount of water delivered to the channel ${ }^{56,57}$. 
Additional information on groundwater abstraction or inter-basin water transfers can be obtained from national scientific agencies, municipal water suppliers or private water companies.

\section{Segment}

Geomorphological characteristics at the segment level relate to the boundary conditions that dictate channel form and processes, including valley setting (gradient and width); river channel gradient; river flows and levels; sediment delivery to the channel; and natural riparian vegetation.

\section{Valley setting (gradient and width)}

The valley setting is influenced by forces operating at vastly different timescales, from tectonic uplift acting over millennia to valley blockage by landslides and glacial surges inducing very rapid geomorphic response. These forces can alter the valley gradient, impacting upon river energy and sediment transport, and the valley width, which in turn impacts the planform and lateral mobility of the river as well as the extent of the active floodplain.

Methods from all four of the approaches (Table 2) are typically used in combination to identify, confirm and date topographic features in the landscape that are indicative of changes in valley setting ${ }^{58-60}$. These features, such as river terraces and palaeo-landslides, are identified using geomorphological surveys and remote sensing techniques and may be depicted on historical topographic maps. Stratigraphic, sedimentological and dating techniques are used to confirm the origin of the features and constrain the dates for their formation. Indicators of changes in valley setting, such as inset river terraces, can also be associated with rapid channel narrowing and incision caused by anthropogenic interventions ${ }^{61}$. These changes are discussed in more detail in the following sections, but it is important to point out here that in addition to the changes that occur in channel geometry and bed level, the floodplain width may be severely diminished, which can have significant implications for the conveyance of high flows and the distribution of riparian vegetation.

Anthropogenic structures that influence the valley gradient and effective valley width should also be studied. Large dams that span the width of the floodplain have a profound and immediate impact on the water surface slope, and cause significant changes in upstream bed elevation over time due to sediment deposition as well as profoundly influencing the flow regime and sediment delivery downstream . Extensive artificial levée networks associated with flood control structures or infrastructure (e.g. rail and road embankments) constrict the valley width, limiting the spatial extent of flood inundation and restricting the lateral mobility of the channel. Information on engineering structures can be obtained from maps, government records, or can be identified from aerial photographs and remotely-sensed data. Semi-automated approaches have been developed to identify and classify earthworks in floodplains from DEMs, satellite multi-spectral data and aerial photography ${ }^{62}$. By linking the spatial representation of engineering structures with a timeline of their constructions and flood levels, it becomes possible to quantify changes in floodplain width over time.

\section{Channel gradient - Changes to longitudinal profile}

Channel gradient is set initially by the valley setting, but is further controlled by planform pattern and geometry. Channel gradient will naturally adjust over time, in response to normal geological and geomorphological processes. Significant changes in channel gradient over short timescales, though, 
are often caused by anthropogenic modifications to the channel or catchment, such as changes to channel planform (i.e. channel realignment and meander cut-off), bed level (e.g. weirs, dams and gravel mining) or sediment delivery from the catchment. Channel gradient is one of the fundamental properties that determine the amount of fluvial energy available to transport sediment within the river channel.

An investigation of changes in channel gradient requires information on two variables at multiple points in time: (i) the length of the river in the segment, and (ii) the bed elevation at a minimum of two locations along the segment. In some situations, this information can be gathered from remote sensing sources, but the most reliable data come from historical sources, particularly systematic river topographic surveys. Accurate topographic surveying of rivers began in the mid-19 $19^{\text {th }}$ to early $20^{\text {th }}$ century in Europe and North America due to the development of rivers for navigation, flood control, and water resources, and offers a wealth of data for historical analyses of fluvial geomorphology ${ }^{63,64}$. For example, repeated topographic surveys have been conducted in many European rivers and have been successfully used to quantify bed aggradation and incision associated with climate change and anthropogenic impacts ${ }^{61,65-67}$ (Figure 4). Care must be exercised when comparing historical bed-levels as problems can arise due to differences in geographical reference systems, survey techniques, or in the attribute measured (e.g. average bed, thalweg or water surface level) ${ }^{64}$.

When systematic surveys are unavailable, channel gradient can be estimated by combining channel length and bed level estimates from different sources, or from gauging station records. Channel length can be derived from plan sources including maps, aerial photographs and other remotelysensed datasets, whilst bed-level change can be derived from cross-sectional surveys conducted for other purposes, such as bridge construction and maintenance, flood risk management or river restoration ${ }^{68-70}$. Changes in bed level can also be inferred from gauging station records in an approach known as specific gauge analysis, in which water surface levels at set discharges are compared over time using empirical ratings curves for each year of the analysis to reconstruct average bed elevation ${ }^{71}$.

If no quantitative information on historical bed levels is available, then some indication of bed level changes can be inferred from a field survey. For example, inset floodplain terraces, undercut bridge piers and exposed bedrock / former floodplain layers in an alluvial river may all indicate incision ${ }^{72,73}$. Conversely, buried engineering structures, large uncompacted point bars, and thick fine sediment deposits overlying a gravel bed may indicate aggradation. The occurrence of these properties varies depending on the catchment characteristics and the location of the segment within the catchment, so must be assessed by an experienced geomorphologist. Field surveys of bed level change should be conducted at multiple locations within a segment to ensure a reliable assessment. Stratigraphic, sedimentological and botanical evidence can support conclusions drawn from a geomorphological survey and help to constrain the timing of bed level changes ${ }^{74,75}$.

\section{River flows and levels}

Information on spatial and temporal variations in river flow and level are vital to any analysis of temporal river change, since they are the primary control on sediment mobilisation, transport and deposition which in turn induce land form change. The most accurate and complete records come from river gauging stations, but some information can also be obtained from remotely sensed data and documentary sources.

Many indicators can be extracted from river flow records (e.g. average and extreme flows and their timing) ${ }^{76}$ and can be used to estimate hydrological alteration ${ }^{77}$. Gauging station records spanning at 
least 20 years ${ }^{78}$ are required for this type of analysis with a minimum temporal resolution of one day, or less if short-term events such as hydropeaking are significant. The entire time series can be analysed to investigate temporal trends, in magnitude, frequency, timing, duration and rate of change in flow; divided into time periods related to significant changes in the flow regime (e.g. preand post-dam construction); or applied to observed and 'naturalised' flows, where the latter take account of modifications attributable to flow abstractions or additions. In the second and third options, indicators are extracted from the pre- or naturalised time series and compared to the postor observed time series to assess hydrological alteration ${ }^{77}$. Different flow characteristics may be significant in different climatic regions and morphological settings ${ }^{76,79}$. Changes in any of these indicators through time or in comparison with natural or 'naturalised' conditions will be accompanied by hydromorphological changes within the segment and, in most cases will affect downstream segments as well. Whilst small shifts may be attributable to climate change, major shifts usually reflect human interventions, with hydropeaking being a distinct indicator of artificiality in the flow regime. Figure 5 illustrates how dam construction and operation can impact maximum annual flow, monthly average flows and daily flows.

Other useful geomorphological indicators are total and specific stream power. Total stream power $(\Omega)$ is the rate of energy dissipation per unit downstream length $\left(\mathrm{W} \mathrm{m}^{-1}\right)$ and is calculated as

$$
\Omega=p g Q s
$$

where $\rho$ is the density of water $\left(1000 \mathrm{~kg} \mathrm{~m}^{-3}\right), \mathrm{g}$ is acceleration due to gravity $\left(9.8 \mathrm{~m} \mathrm{~s}^{-2}\right), \mathrm{Q}$ is discharge (in $\mathrm{m}^{3} \mathrm{~s}^{-1}$ ) and $\mathrm{S}$ is slope (in $\mathrm{m} \mathrm{m}^{-1}$ ). A morphologically-meaningful discharge indicative of, for example, bank full conditions is most informative. Thus the median annual maximum flow (Qpmedian) or the annual flood with a 2, 5 or 10 year return period have all been used for this purpose. Specific stream power is stream power per unit channel width $\left(\mathrm{W} \mathrm{m}^{-2}\right)$ and is calculated by dividing total stream power by the average channel width for the segment. Stream power has been correlated to a wide range of geomorphological forms and processes, including channel size, planform pattern, sediment transport and island formation ${ }^{80-85}$.

Where river gauging station records do not exist, modelling, remote sensing, historical records and palaeo appraoches can be used to estimate aspects of the flow regime. For example, the UK's 'Flood Estimation Handbook' presents methods to estimate flood indicators (e.g. Q $p_{\text {median }}$ ) for ungauged sites based on attributes of the catchment, river network and precipitation in the UK ${ }^{50}$. Remote sensing can provide information on the spatial extent or elevation of the water surface that can be used, for example, to estimate flood levels and extent. River discharge cannot be directly quantified from remotely-sensed data, but can be estimated from altimetry data by calibrating river level with gauging station records or through the use of hydraulic relationships ${ }^{48,86}$. Observations of flood levels and extents can also be obtained from documentary sources and combined with hydraulic modelling to reconstruct flood discharge, which can extend the analysis further back in time ${ }^{87}$. Lastly, palaeo-hydrological techniques can be used to estimate bankfull flow based on cross-section or planform geometry of palaeo-channels ${ }^{88-90}$ and flood records based on fluvial sediment deposits 91,92 .

Finally, to assess the impacts of human intervention on the flow of water in the river, a chronology of anthropogenic changes in the segment should be constructed. Of particular interest are the dates of construction and the size of water flow impedances or storage structures, be they for water diversion, hydropower, flood management or water consumption purposes. Information to complete the chronology can come from any number of historical sources, including maps, aerial photographs and water company records. 


\section{Sediment delivery}

Sediment delivery refers to the transfer of sediment from the areas of production identified at the catchment / landscape scale to the river channel. The importance of coupling (i.e. connectivity) between channels and adjacent hillslopes has been long acknowledged ${ }^{93-95}$. Evaluation of the degree of coupling, and its change through time, is critical to drainage basin sediment dynamics as it controls in what proportion hillslope sediment flux contributes to drainage basin sediment storage and fluvial sediment yield respectively ${ }^{96,97}$. Remote-sensing and field mapping are the most commonly used approaches for discrete sediment sources, whereas the palaeo approach is the preferred method for investigating diffuse sediment sources, particularly of fine sediment.

In the remote sensing approach, DEMs are used to track changes in the topography of sediment sources over time to estimate sediment delivery to the channel. For coarse sediment, the sources are typically discrete and in close proximity to the river channel (e.g. landslides), whereas for fine sediment they can be discrete (e.g. earth flows) or diffuse sources (e.g. soil sheet erosion). The DoD method works best with discrete events for which there are DEMs that characterise the topography before and after the event, preferably with multiple post-event DEMS to permit the calculation of delivery rates. DEMs derived from photogrammetry, field surveys and LiDAR can all be used, but consideration must be given to the uncertainty in the topographic measurements and the amount of change being detected. For example, uncertainties in LiDAR-derived elevation measurements are still in the centimetre to decimetre range, so care must be exercised in interpreting topographic change over short time spans, or when the amount of change being detected is of similar magnitude to the positional accuracy ${ }^{98-100}$. A process-based geomorphological mapping method, which combines field surveying and remote sensing approaches, can be particularly useful for assessing coarse sediment connectivity and transfer ${ }^{101}$.

Palaeo approaches are the primary empirical methods for estimating the delivery of fine sediment to the river channel. Stratigraphic and sedimentological interpretation of sediment deposits from the channel bed, overbank deposits, fill deposits in cutoffs and avulsions, and reservoir/lake sediments can determine the amount, timing and source of sediment ${ }^{91,92,102-105}$. Additional topographic and historical data (e.g. historical maps, diaries, photographs, legislation) can corroborate the evidence gathered from palaeo approaches, and can illustrate the impacts of altered sediment delivery on fluvial forms and processes ${ }^{106}$. Cosmogenic approaches are particularly useful for sediment budgeting ${ }^{98,107}$, but may only be feasible in areas with severe or complex fine sediment delivery problems due to the cost and expertise involved. Alternatively, soil erosion models can be combined with information on changes in land cover / land use, precipitation to predict changes in fine sediment delivery ${ }^{108-110}$.

Finally, temporal changes in sediment delivery may be identifiable in field surveys of the river channel ${ }^{18,111}$. For example a decrease in coarse sediment supply may result in bed incision, bed armouring, a reduction in geomorphic features or a change in river pattern (e.g. from braided to wandering). An increase in fine sediment delivery may result in the clogging or burial of a coarsegrained bed, bed aggradation, and the presence of fine sediment geomorphic features (e.g. silt bars and benches).

\section{Riparian vegetation and wood}

This section covers the analysis of riparian vegetation characteristics for both the segment and reach scales. Riparian vegetation is not only important from an ecological perspective, but its extent and structure can indicate past river dynamics and the potential character size and quantity of wood to the river. Wood delivery in turn has important influences on flow hydraulics, sediment retention and 
landform construction within the river channel and its margins, as does the extent and morphological structure of aquatic vegetation ${ }^{112,113}$. At the segment scale, the key characteristics include the size, width and continuity of the riparian corridor and the potential for wood recruitment to the river. At the reach scale they relate to the structure, spatial distribution and species composition of the riparian vegetation; the species, abundance, morphology (i.e. submerged / emergent) of aquatic vegetation; and the presence of large wood in the channel and its margins. Similar data sources and methods are used at each scale, but the level of detail required is higher for the reach scale. The primary sources of information come from remote sensing and ecological field surveys (not discussed here), although detailed land survey maps can contribute to the analysis.

Remotely-sensed data is perhaps the best source of information to assess change in riparian vegetation over a decadal timescale, including aerial photographs; multi- and hyperspectral data from airborne or satellite-based platforms; and airborne LiDAR ${ }^{114-119}$. The choice of remotely-sensed data for a particular river segment depends upon data availability and the spatial resolution of the data in comparison to the width of the riparian corridor and the amount of change being detected. For rivers with large and continuous riparian vegetation cover, small-scale aerial photography and freely-available satellite imagery can be used to assess segment scale characteristics. For segments with narrow or patchy riparian vegetation and for all reach-level characteristics, higher resolution data is needed. For guidance on scale and resolution for vegetation identification and classification, see Table 3. Classification methods are similar to those presented earlier for LCLU, though additional supporting information is often needed (e.g. DEMs and floodplain extents).

Where available, LiDAR data is particularly useful for characterising riparian vegetation structure and spatial distribution. The point cloud data that is generated by LiDAR provides information on the presence of vegetation, vegetation height and canopy structure, which can be used to interpret vegetation type, vegetation age and ground topography ${ }^{116,120}$. LiDAR can also be combined with other remotely-sensed data to more thoroughly characterise riparian vegetation structure ${ }^{116,121}$. Changes over time can be investigated using height frequency distributions, DoDs or areal coverage of vegetation classes (e.g. height or species).

Historical maps can be a valuable resource, particularly large-scale land and tax maps that have detailed land use information associated with them. Historical cadastral maps have been used to assess changes in the extent and composition of riparian vegetation ${ }^{115}$. This information can be paired with modern vegetation survey data to link historical channel change to current vegetation structure and species composition (Figure 6) ${ }^{122,123}$ or to estimate changes in habitat type, age and turnover ${ }^{124,125}$.

Changes in the distribution and frequency of large wood in the channel can be investigated effectively using remotely-sensed data, including vertical and oblique aerial photography ${ }^{126}$, airborne hyperspectral data ${ }^{127}$, and a combination of LiDAR, oblique ground photographs and field surveys ${ }^{128}$. Structure from Motion (SfM) photogrammetry may be useful for this purpose, particularly using ground or low-altitude aerial photography (e.g. a camera on a pole) ${ }^{129,130}$. SfM is a newly-developed technique in geomorphology that can generate DEMs from any series of overlapping digital photographs with positional accuracies as good as LiDAR. This opens up the possibility of tracking volumetric changes in large wood using DoDs from historical photos.

Finally, information on riparian vegetation and large wood can come from other historical sources such as travel accounts, ground photographs and government policy/records ${ }^{63,131}$. For example, large wood may have been, and may still be, removed from channels by the local population for use as fuel or to improve drainage and reduce local flooding, and by governments to maintain channels and protect infrastructure. Any information on how the spatial extent and intensity of these practices has varied over time will help to develop an understanding of how large wood has influenced the current and past geomorphological condition of the river. 


\section{Reach}

Whilst the characteristics investigated at the larger spatial scales were largely associated with controls on geomorphology, those at the reach scale are primarily indicators of function, channel adjustment or alteration / artificiality. Geomorphological characteristics are grouped into three categories: planform morphology and channel migration; channel geometry; and bed sediment calibre. Riparian vegetation, aquatic vegetation and wood should also be assessed at the reach scale, but this has already been discussed in the segment-scale description above.

\section{Planform morphology and channel migration}

This section addresses changes in the 2-dimensional form of rivers over time, and includes river planform and associated characteristics (e.g. channel width and sinuosity, braiding and anabranching indices); channel migration; and geomorphic units within the channel or floodplain. This encompasses a large variety of characteristics, but they are united by the data sources and analytical techniques used to investigate temporal change ${ }^{132}$. Analysis of these characteristics (e.g. channel pattern, channel width) allows reconstruction of evolutionary trajectory of river morphology. This is crucial in river management for understanding present morphology and processes and predicting possible channel evolution in the near future.

The analysis of temporal change in planform relies primarily on remotely-sensed data and historical maps. In fact, these sources are often used in combination. Aerial photographs or satellite data are frequently used to characterise recent planform, and historical maps to extend the analyses further back in time. The basic premise of the analysis is to overlay images from multiple years and check to see if there has been a change in the position of a feature (e.g. bankline, Figure 7) or a change in the characteristics of a feature (e.g. channel width, Figure 3). Because this type of analysis is based on a comparison of geographical positions, it is crucial that the data sources are properly registered to a common coordinate system in a GIS and accuracy / uncertainty is estimated for each source and at each time point.

Maps, aerial photography and satellite imagery can all be used to investigate temporal changes in rivers that cover the full range of sizes, patterns and dynamics. The major consideration is the scale of the data sources in relation to the size of the feature being detected (e.g. channel width) and the amount of change being detected (e.g. lateral migration). Consequently, studies of temporal change in narrow or slowly adjusting rivers need large-scale maps and aerial photographs (minimum 1:10,000 scale) or high resolution satellite imagery ${ }^{133-136}$. Large and dynamic rivers can be studied with smaller-scale maps and aerial photographs ${ }^{117,137-139}$ or with coarse-resolution satellite data ${ }^{140-}$ 142. Infrared bands of multispectral satellite data, e.g. MODIS band 2 or Landsat Thematic Mapper band 5 , can be used to automatically segregate water and land based on a pixel threshold and so to differentiate banklines, particularly for large rivers with clear water ${ }^{143}$. In addition, well-tested band ratios can be used to discriminate vegetated from unvegetated surfaces (Normalised Difference Vegetation Index ${ }^{144}$ ), and wetter from drier surfaces (Modified Normalised Difference Water Index ${ }^{145}$ ). Maps, aerial photography and satellite data can also be used to identify geomorphic features within the channel and track changes in their size, frequency and location over time ${ }^{146-149}$.

Geomorphological surveys can provide insights into channel migration and changes in channel width, particularly when combined with botanical, sedimentological or stratigraphic evidence ${ }^{150,151}$. For example, channel narrowing can be identified from active accretion of sediment on opposite banks, particularly when such accretion is stabilised by vegetation encroachment. The species composition and age structure of riparian vegetation can also provide clues to the direction of 
channel change. For example, lateral banding in the height and ground cover of riparian vegetation due to vegetation succession can underpin estimates of lateral migration extent and rates ${ }^{152,153}$ and modes of lateral floodplain construction ${ }^{154,155}$, whereas lateral and downstream changes in the species composition or morphological structure of riparian vegetation can be indicative of distinct geomorphic features, subject to contrasting inundation and soil moisture regimes ${ }^{156}$. Thus changes in vegetation structure and composition can reveal channel bed incision or aggradation ${ }^{75}$ through their influence on moisture conditions within the geomorphic features ${ }^{157}$. To go further back in time, the planform configuration of palaeochannels can be investigated based on their topographic signature in the floodplain and supported by sedimentological and stratigraphic evidence ${ }^{158,159}$.

Finally, the chronology of physical pressures should be updated with the dates and extent of river realignment and channel bank and bed reinforcement. This information can come from maps, remote-sensing and water agency records.

\section{Channel geometry}

Channel geometry refers to the cross-sectional form or bed configuration of a channel. Changes in channel geometry over time can indicate changes in the flow or sediment regime or direct channel interventions such as sediment removal (mining). These are all important indicators of instability that need to be taken into account if any channel management or restoration is envisaged. They are also indicators of induced changes in other processes, for example, bank hydrology and flow hydraulics, that may in turn impact on riparian as well as the aquatic ecology. Whilst information on channel width can be gained from maps and aerial photography, additional data are essential for a full characterisation of channel geometry. The recommended data source for this analysis is topographic surveys, although several remote-sensing approaches are applicable in certain situations.

Cross-sectional surveys are the core data sources to examine changes in channel geometry over time. They are conducted across the river channel, perpendicular to the flow direction, and provide a wealth of morphometric information about the channel (bankfull and low flow channel width, bedlevel, water level at the time of survey, bank profiles, etc.) as well as indices used in hydraulic modelling (e.g. bankfull cross-section area and hydraulic radius). In regions where a network of cross-sections has been established for regular monitoring, cross sections from different points in time can be easily overlaid to investigate changes in channel geometry (Figure 8). However internal checks on the surveys should still be conducted to ensure that the same reference points and start / end locations have been used and that there has not been a change in the survey approach which would affect the way the survey was conducted, the accuracy of the measurements or the interpretation of landforms.

Remote sensing approaches to characterise channel morphology fall into two categories. The first uses altimetry data from photogrammetry, LiDAR or TLS to create 3D models of the channel bed, i.e. DEMs. The DEMs are then used to identify features, detect changes in the morphology over time and even calculate volumetric differences over time. This approach is mostly applicable to shallow, wide rivers for which a substantial portion of the bed is exposed. Large gravel-bed rivers have been studied extensively using this method ${ }^{160-164}$. However high resolution LiDAR and TLS have been applied to the study of bank and cliff erosion in meandering rivers in conjunction with aerial imagery 165,166 , and recent work has demonstrated the potential for automated extraction of channel networks and bank faces from LiDAR ${ }^{35,167-169}$. LiDAR has an additional use in bathymetric data collection. Bathymetric LiDAR can measure the bed topography of water bodies up to ca. $60 \mathrm{~m}$ depth with high vertical accuracy. It does not suffer from problems associated with sun glint, shadows or surface disturbances like the spectral approach described below, but its application is limited to 
waters with low suspended sediment concentrations and is not suitable for application to very shallow water ( $<1.5 \mathrm{~m}$ deep $)^{170,171}$. Whilst the focus of discussion on remote sensing techniques throughout this review is on airborne and satellite approaches, it is worth pointing out that bathymetric sonar ${ }^{172,173}$ and other related acoustic devices (e.g. sub-bed profiler ${ }^{174}$ ) can be used to map and detect changes in riverbed topography.

The second approach estimates water depths using the spectral signature of aerial photographs and multi / hyper spectral data ${ }^{171}$. This technique is well developed and has been used successfully to study changes in many types of water bodies, particularly coastal areas. It is used increasingly to characterise river bed topography (e.g. from aerial photography 162, 164, 175-177; airborne multi- and hyper spectral data; ${ }^{127,175,178,179}$; multi-spectral satellite data ${ }^{180}$ ). Although analysis of remotelysensed data can provide good characterisation of spatial changes in water depth, the absolute accuracy of the depth estimates depends on calibration using synchronous water depth measurements. This has limited the use of spectrally-derived depth measurements in historical analyses, but see Ref 162 for one solution to the problem of ground-truth data for historical aerial photographs. Furthermore, spectrally-based bathymetry is limited not only to shallow water depths (typically a few metres) but also requires clear water conditions, substrate with bright and reflective surfaces, good illumination, and minimal atmospheric interference ${ }^{181}$.

In some circumstances, a geomorphological field survey may be the only available option to assess changes in channel geometry over time. This may be true for remote, narrow or slowly-adjusting streams which may not be represented on maps or may be subjected to high levels of uncertainty in spatial position which exceed the amount of change being detected. Channel widening can be evidenced by bank erosion or undercutting on opposite banks, whereas channel narrowing can be indicated by stabilising, vegetated bars or benches on both banks. Field evidence of bed level changes was discussed earlier in the channel gradient section.

\section{Sediment transport and bed sediment size}

Information on bed and bank sediment size and sediment transport are crucial to understanding the geomorphological style and likely dynamics of rivers. Changes in the sediment regime, specifically in bedload transport, can cause channel instability that results in changes to channel planform, bed levels and type, geomorphic features, etc. Therefore information on sediment transport is key for sustainable, process-based river management and restoration.

When available, long-term monitoring data for suspended sediment and bedload provide invaluable information on sediment transport within a reach. Suspended sediment is more commonly monitored than bedload transport, as it is an aspect of water quality that is typically measured by water companies and national environmental agencies. Bedload is more difficult to quantify, and consequently monitoring stations are usually located only in areas where bedload poses a very significant river management problem ${ }^{182}$. These sources can be readily analysed and combined with river flow information to assess changes in sediment delivery and transport over time ${ }^{183}$.

Unfortunately, sediment transport is not monitored as commonly as water discharge, and many rivers have very limited or no sediment monitoring record. In this situation, changes in sediment delivery and transport associated with human disturbance to the system can be explored by creating a historical inventory of engineering structures that impact the lateral or longitudinal transport of sediment (i.e. sediment connectivity). For coarse sediment these structures can include dams, check dams, weirs and torrent controls ${ }^{67,184}$, whilst for fine sediment they can also include drainage ditches in the catchment and artificial levées ${ }^{106}$. Depending on the catchment history, it may also be pertinent to acquire data for sediment-related activities within the channel, such as records detailing 
the quantity and location of sediment dredging or mining from the channel ${ }^{185,186}$. This inventory can be combined with information on land cover, topography, and sediment delivery collected at the catchment / landscape unit and segment scales to formulate an integrated chronology of sediment flux.

Remote sensing has enormous potential for use in sediment transport estimates and sediment budgets. This includes the detection and estimation of volumetric change in bed topography (i.e. the morphological approach") from aerial photos ${ }^{187}$ or high resolution DEMs ${ }^{160}$, as well as monitoring fine sediment concentrations using aerial photography and multispectral satellite data ${ }^{188,189}$. The morphological approach to estimate bed-load has been successfully used in numerous studies ${ }^{187,190-}$ ${ }^{192}$, in particular where direct measurements using samplers are difficult to carry out or where it is not possible to capture the wide spatial and temporal variability of sediment transport (e.g. in large gravel-bed rivers). Besides, it has been shown that morphological methods provide reasonably robust estimates of the time- and space-averaged bedload transport ${ }^{193}$. These approaches rely on morphological changes, requiring comparison of DEMs of river channels ${ }^{194}$ or cross-sections ${ }^{67}$. Considering the increasing availability of LiDAR data, but also the possibility of deriving DEMs from archival aerial photos ${ }^{162}$, there will be more and more opportunities to apply morphological approaches for sediment transport estimation. Even in the absence of favourable conditions for estimation of bed-load transport (the morphological approach requires that sediment transport is known at one cross-section within the study reach), comparison of DEMs represents the best tool for calculation of the sediment budget and, therefore, for assessing the evolutionary trend of channel morphology in a given reach.

Temporal changes in bed sediment calibre can be investigated using remote sensing, field surveying and palaeo approaches. Techniques have been developed for the extraction of bed material size from aerial photography based on image texture ${ }^{195-199}$. For shallow rivers with non-turbid water, these techniques offer the possibility of extracting sediment sizes from archival aerial photos to assess change over time, particularly in light of recent analytical developments that allow for automated sediment size measurement without the need for field calibration ${ }^{200}$. If photographybased methods are not appropriate, a combination of field survey, stratigraphy and sedimentology can be used to identify morphological forms and structures that are indicative of a change in bed calibre (e.g. bed armouring or extensive fine sediment deposits in a gravel-bed river) and to quantify the timing and magnitude of change.

\section{ACCURACY, UNCERTAINTY, AND ERROR}

All data is subject to error, and so a careful appraisal of error is essential to scientific data analysis. Accuracy, uncertainty and error are related, are frequently used interchangeably, and are all associated with the reliability of the data to represent the true form or process in nature ${ }^{201}$. The differences are subtle. When errors have been quantified for a particular data source, they are typically referred to as 'accuracy'; when they are unknown or not clearly defined, the term 'uncertainty' is used; and the term 'error' is used variously and often when it is quantified by the user. In this section, we use accuracy preferentially, and reserve uncertainty or error for the discussion of estimation methods when accuracy is not defined in advance for a dataset.

\section{Types of accuracy}

Accuracy can by subdivided into 3 components: position, attribute and time ${ }^{202,203}$. Positional accuracy refers to the location of a feature on a graphical representation (e.g. map, photograph or 
remotely-sensed dataset) in relation to other features (i.e. relative accuracy) or its true location in nature (i.e. absolute accuracy). It is influenced by the methods employed to collect, interpret and display the data. For example, the absolute accuracy of a river drawn on a map is dependent on the accuracy of the original survey or the resolution of the aerial photographs it is derived from; the interpretation of a feature from those sources (e.g. banklines); the geographical projection used; and the purpose and scale of the map. Positional accuracy is routinely quoted for national/regional maps and satellite datasets. For example, a 1:10,000 scale UK Ordnance Survey map represents rivers at their true scale, with two banklines, when the river channel is at least $5 \mathrm{~m}$ wide. Average positional accuracy is quoted at $\pm 4 \mathrm{~m}( \pm 7 \mathrm{~m}, 95 \%$ confidence level), meaning that the channel's location on the map is on average $4 \mathrm{~m}$ off relative to its true position, and most points are within $7 \mathrm{~m}$. Larger-scale maps typically have higher positional accuracy. A UK Ordnance Survey map at 1:2500 scale represents rivers to scale when they are $2 \mathrm{~m}$ wide, and has an absolute accuracy of $\pm 2.8 \mathrm{~m}$. When comparing maps over time in a diachronic analysis, a threshold for planform change detection must be set that incorporates the positional accuracy of each source.

Attribute accuracy relates to how the identification of a feature or the characteristics of a pixel compares to its true characteristics at that location. Some degree of interpretation, simplification or classification is inherent when data is recorded, analysed and displayed graphically, whether this was done by the original surveyor and mapmaker of a historical map or a satellite-based sensor and a GIS technician, so attribute accuracy is always an issue. For example, for satellite-based multispectral data, the spectral signature of a feature is influenced by the spatial resolution of the data relative to the feature size, as well as by changes in illumination (e.g. sun angle), atmospheric conditions (e.g. clouds or haze), and viewing geometry ${ }^{25}$. The spectral signature is then processed, interpreted and classified, all of which can affect attribute accuracy. If features are small relative to spatial resolution, pixels will represent more than one feature (i.e. mixed pixels), adding additional uncertainty to feature identification or classification. Techniques have been developed to help overcome this problem, e.g. classification of mixed pixels for land cover using fuzzy logic ${ }^{25}$, 204, but in general it is best to consider the spatial scale of a feature $a$ priori when selecting a data source.

Temporal accuracy relates to the reported date for the observations or data. This is primarily a concern for historical data sources, such as maps and documentary evidence. For example, the time lag between the initial field survey and the publication of a map can vary substantially. Often with historical maps, a single publication date is listed for the entire map collection, even though locations were surveyed and map sheets produced at different times. An additional problem with maps is partial resurveying, in which only a portion of an earlier map is updated and labelled with the new date. These resurveys introduce significant temporal uncertainty if the extent of the resurvey is not indicated. Temporal accuracy is less of an issue for remotely-sensed datasets, which are typically time/date stamped at collection or processing, but can be a problem for archival aerial photographs.

\section{Assessing accuracy / uncertainty}

A wide range of data sources can be used in the analysis of temporal change in river form and processes. These sources differ substantially in their inherent reliability and it is extremely important that sources are assessed prior to inclusion into a study. Assessment involves a series of internal and external checks that verify the positional, attribute and temporal accuracy of a source ${ }^{205}$. For example, a historical map can be checked to see if it is a partial resurvey by examining accompanying records, comparing the map against earlier or later ones from the same source, or comparing the map to other sources from the same time period (e.g. land survey records, aerial photograph). If the data sources are judged to be sufficiently reliable for the analysis, the accuracy or uncertainty of the data can be estimated and integrated with the other sources in the temporal analysis to support 
change detection. In the remainder of this section, further information is provided on estimating positional and attribute accuracy / uncertainty.

When not reported for a data source, positional accuracy can be estimated by comparing positions on the graphical representation with their true location (e.g. ground control points) or with locations on a map or digital product with higher accuracy. When using a GIS, this process takes place when the data source is registered to a geographical projection (i.e. georeferencing). To illustrate this, we provide an example using historical maps. A similar procedure would be conducted with aerial photographs, however there are additional steps that should be taken to correct for image distortion or perspective, i.e. orthorectification (for an introduction see a relevant textbook ${ }^{206}$ ). A historical map is typically registered to a coordinate system by identifying common landmarks on a modern large-scale map ${ }^{207}$. Landmarks should be stable in space and time (e.g. a building), as precise as possible (e.g. the corner of a building), and evenly distributed over the map. Geometric transformations are then used to alter the scale, displacement and rotation of the historical map ${ }^{208}$. For most maps, a first-order transformation should be used unless there is significant evidence of shrinkage and distortion of the paper map ${ }^{133}$. The output of this process is an average displacement of positions on the historical map, which is typically represented as a root mean square error (RMSE) and often used to assess positional accuracy ${ }^{209}$. However, methods to estimate positional error and how it propagates through data analysis have advanced significantly, and recent work provides further details on methods and underlying assumptions ${ }^{163,201,208,210 .}$

Attribute accuracy / uncertainty is discussed here with a focus on raster datasets. Numerous techniques are available to assess uncertainty and detect change, and the choice is dependent on the data and type of change being detected ${ }^{211,212}$. For land cover, error mis-classification matrices are commonly used post-classification to estimate attribute accuracy and detect change ${ }^{213,214}$. A fuzzy logic approach is particularly appropriate when attribute classes are not standardised over time or between sources ${ }^{204,215}$, and a multi-layer (GIS-based) approach can be useful when multiple data sources are integrated for the classification ${ }^{211,212,214}$. A direct comparison of pixels between years can be used, but this approach is more sensitive to positional and attribute errors.

An attribute that deserves special attention is elevation. DEMs are datasets with elevation as an attribute, and a characterisation of uncertainty in these measurements is essential for detecting changes in topography over time using DoDs. Similar to the discussion of 2D change detection, volumetric change detection can use a single threshold of change or a more advanced spatially distributed approach ${ }^{160,216}$.

\section{APPLYING THE TEMPORAL ANALYSIS OF GEOMORPHOLOGICAL CHANGE TO RIVER RESTORATION AND MANAGEMENT}

A temporal analysis allows us to peel back the layers of time to explore what a channel and its floodplain looked like in the past, how they have changed over time, how quickly these changes have occurred, and what the role of human interventions is in these changes. In other words, it supports holistic, sustainable river restoration and management by permitting the quantification of hydrological and geomorphological processes (e.g. water flow, sediment transport, riparian and aquatic plant growth and succession), the identification of natural and human-induced alterations to these processes, and the estimation of the impacts of alteration on geomorphological process rates and forms within a reach. This information allows managers to identify the root causes of geomorphological change in river-floodplain ecosystems, identify constraints on restoration potential, and assess the possible trajectories and timelines of change under different management scenarios ${ }^{138}$ (Figure 9). 
Geomorphological degradation of a reach is caused by changes that have occurred both within the reach itself and at larger spatial scales. The loss of physical habitat over time may be related to direct physical alteration of the reach in the past or current management practices, but equally it may be the symptom of hydrological and geomorphological changes that have occurred upstream (or downstream) of the reach or in the wider landscape in the past. For example, changes in land cover / land use will alter water and sediment production at the catchment/landscape scale, which impacts the delivery of water and sediment to the channel and floodplain at the segment scale, and which ultimately affects channel planform, dimensions, bed levels, bed sediment size and transport and the creation of the hydraulic and geomorphic features that support aquatic and riparian ecosystems at the reach scale. Urbanisation of a catchment is an excellent example of this cascade. Numerous studies have shown how changes to sediment and water delivery, flow regimes and riparian vegetation associated with urbanisation can cause reach-scale problems such as channel incision, widening, bed armouring and a decrease in the diversity and frequency of geomorphic features ${ }^{20}$, ${ }^{217}$. In this example, a temporal analysis of geomorphology would allow practitioners to quantify changes in land use, channel gradient, channel cross-sectional form / width and the extent and type of riparian vegetation, and to determine how the key geomorphic processes have been altered (e.g. runoff generation, sediment delivery, river flows, sediment transport, etc.). By identifying these root causes of temporal changes at reach scale, restoration and management strategies can be developed to target the underlying processes to allow for a better geomorphological functioning of the channel-floodplain ecosystem or to support a comprehensive restoration plan, rather than simply tackling the symptoms of the degradation.

Once the underlying causes of geomorphological degradation are identified, the potential for restoration of those processes can be appraised. In heavily-modified catchments or those that support large human populations, industries or services, it is unlikely that all of the processes will be restorable and some human constraints on geomorphological processes will have to persist. In these situations, an assessment is needed on how the impacts of these constraints can be minimised. For example, hydropower dams may be required in the headwaters of a river for the medium- to longterm to provide electricity for urban or industrial areas further downstream. Whilst a disruption to bedload transport may be unavoidable for a large dam, changes to the dam operation can minimise the impacts on the flow regime by mimicking natural flow magnitude, timing, duration and frequency ${ }^{218}$. In this example, the temporal analysis of river flows allows practitioners to identify what the natural flows would have been prior to human interventions and to establish patterns of flow (daily, seasonal and annual) that are as close as possible to the natural ones. Other impediments to coarse sediment delivery downstream of the dam can be identified, and, if appropriate, removed to reconnect the coarse sediment supply to the channel. If the major alterations to geomorphology cannot be remedied, then it becomes necessary to target the reachscale symptoms in light of the current altered processes in order to increase geomorphological diversity and maximise ecological benefits.

Finally, with an understanding of the hydrological and geomorphological processes and human constraints, we can begin to predict the evolutionary trajectories of the river and floodplain under different management scenarios, set management end goals, and estimate timescales for change ${ }^{7}$, ${ }^{219}$. Previous conditions of the river and the direction and rates of change that resulted from alterations to hydrological and geomorphological processes in the past give an indication of how a channel and floodplain will respond to future changes. Practitioners are referred to a range of approaches that can aid the development of evolutionary trajectories: assessment frameworks ${ }^{15}$; conceptual and empirical models of channel evolution ${ }^{220-222}$ and channel and floodplain morphologies ${ }^{81,223}$, and numerical models of morphodynamics and sediment transport ${ }^{224,225}$. It is important to stress that past condition does not mean reference condition. Human interventions to rivers and catchments extend back centuries to millennia depending on the region, and historical condition is instead an image of what the river and floodplain looked like under those boundary 
conditions and how it changed when those conditions were altered. Restoration should aim to restore geomorphological function or work within the current boundary conditions (water flows, sediment fluxes, etc.) to develop obtainable and sustainable targets. The rates of change in the system provide an indication of the potential and timescale for natural channel evolution. Dynamic rivers that adjust rapidly and respond rapidly to extrinsic factors have the best prospects for renaturalisation. A high energy, gravel-bed river that has incised, narrowed or shifted to wandering planform because of sediment control and exploitation has a good potential to reach a good geomorphological condition in a short period of time once processes are naturalised, because rates of hydrological and geomorphological processes are high. Conversely, a formerly anastomosing river in a lowland setting that was simplified, channelized, straightened and widened may take considerably longer to recover a good condition because process rates are much slower. In these situations, a temporal analysis can provide a guiding principle with which to develop restoration measures.

\section{Conclusion}

The aim of holistic river basin management is to balance the demands of human use and modification of rivers with the preservation and improvement of physical structure and condition to support natural and diverse ecological communities. A process-based approach to holistic river management works with river processes (ecological, chemical, hydrological, geomorphological) to facilitate the development of sustainable management and restoration strategies. An analysis of change in fluvial geomorphology supports this approach through a quantification of the key processes at multiple scales that structure the river and floodplain at the reach scale, an identification of alterations to these processes, and an assessment of how past alterations to the processes have affected and continue to affect the geomorphology of the river and floodplain. This information allows managers to identify the underlying causes of geomorphological change in riverfloodplain systems, identify constraints on restoration potential, and assess the possible trajectories and timelines of change under different management scenarios. The recommendations on hydrological and geomorphological characteristics, data sources and analysis provided in this review form a flexible framework with which to conduct a temporal analysis that develops an improved understanding of how a river functions in response to temporal changes in the spatial hierarchy of processes that influence it and so provides a foundation on which to base holistic and sustainable river restoration and management decisions.

\section{Acknowledgements}

The authors would like to thank Massimo Rinaldi, Marta González Del Tánago, Christian Wolter, Stuart Lane and two anonymous reviewers for their helpful comments on the manuscript, and Ed Oliver for modifying and improving the figures. The review is a product of research conducted on the characterisation of river hydromorphology within the REFORM collaborative project funded by the European Union Seventh Framework Programme under grant agreement 282656. 


\section{References}

1. Dynesius $M$, Nilsson C. Fragmentation and flow regulation of river systems in the northern 3rd of the World. Science 1994, 266:753-762.

2. Syvitski JPM, Vorosmarty CJ, Kettner AJ, Green P. Impact of humans on the flux of terrestrial sediment to the global coastal ocean. Science 2005, 308:376-380.

3. Ward JV, Tockner K, Arscott DB, Claret C. Riverine landscape diversity. Freshwater Biology 2002, 47:517-539.

4. Kondolf GM, Boulton AJ, O'Daniel S, Poole GC, Rachel FJ, Stanley EH, Wohl E, Bang A, Carlstrom J, Cristoni C, et al. Process-based ecological river restoration: Visualizing threedimensional connectivity and dynamic vectors to recover lost linkages. Ecology and Society 2006, 11:5. [online] URL http://www.ecologyandsociety.org/vol11/iss12/art15/.

5. Sear DA. River restoration and geomorphology. Aquatic Conservation-Marine and Freshwater Ecosystems 1994, 4:169-177.

6. Palmer MA, Bernhardt ES, Allan JD, Lake PS, Alexander G, Brooks S, Carr J, Clayton S, Dahm $\mathrm{CN}$, Shah JF, et al. Standards for ecologically successful river restoration. Journal of Applied Ecology 2005, 42:208-217.

7. Dufour S, Piégay $\mathrm{H}$. From the myth of a lost paradise to targeted river restoration: forget natural references and focus on human benefits. River Research and Applications 2009, 25:568-581.

8. Beechie TJ, Sear DA, Olden JD, Pess GR, Buffington JM, Moir H, Roni P, Pollock MM. Processbased Principles for Restoring River Ecosystems. BioScience 2010, 60:209-222.

9. McDonald A, Lane SN, Haycock NE, Chalk EA. Rivers of dreams: on the gulf between theoretical and practical aspects of an upland river restoration. Transactions of the Institute of British Geographers 2004, 29:257-281.

10. Frissell CA, Liss WJ, Warren CE, Hurley MD. A hierarchical framework for stream habitat classification: Viewing streams in a watershed context. Environmental Management 1986, 10:199-214.

11. Montgomery DR, Buffington JM. Channel processes, classification and response potential. In: Naiman RJ, Bilby RE, eds. River ecology and management. New York: Springer-Verlag Inc.; 1998, 13-42.

12. Montgomery DR. Process domains and the river continuum. Journal of the American Water Resources Association 1999, 35:397-410.

13. Habersack HM. The river-scaling concept (RSC): a basis for ecological assessments. Hydrobiologia 2000, 422:49-60.

14. González del Tánago M, García de Jalón D. Hierarchical classification of rivers: A proposal for eco-geomorphic characterization of Spanish rivers within the European Water Frame Directive. In: García de Jalón D, Vizcaíno P, eds. Fifth Internacional Symposium on Ecohydraulics. Aquatic Habitats, Analysis and Restoration. Madrid, Spain: IAHR Congress Proceedings; 2004, 205-211.

15. Brierley GJ, Fryirs KA. Geomorphology and river management: Applications of the River Styles Framework: Blackwell; 2005.

16. Thorp JH, Thoms MC, Delong MD. The riverine ecosystem synthesis: biocomplexity in river networks across space and time. River Research and Applications 2006, 22:123-147.

17. Rinaldi M, Surian N, Comiti F, Bussettini M. A method for the assessment and analysis of the hydromorphological condition of Italian streams: The Morphological Quality Index (MQI). Geomorphology 2013, 180:96-108.

18. Sear D, Newson MD, Thorne CR. Guidebook of applied fluvial geomorphology. London: Thomas Telford; 2010, 262.

19. Sear DA, Newson MD, Brookes A. Sediment-related river maintenance - the role of fluvial geomorphology. Earth Surface Processes and Landforms 1995, 20:629-647. 
20. Paul MJ, Meyer JL. Streams in the urban landscape. Annual Review of Ecology and Systematics 2001, 32:333-365.

21. Owens PN, Batalla RJ, Collins AJ, Gomez B, Hicks DM, Horowitz AJ, Kondolf GM, Marden M, Page MJ, Peacock DH, et al. Fine-grained sediment in river systems: Environmental significance and management issues. River Research and Applications 2005, 21:693-717.

22. Malhi Y, Roberts JT, Betts RA, Killeen TJ, Li WH, Nobre CA. Climate change, deforestation, and the fate of the Amazon. Science 2008, 319:169-172.

23. Rogan J, Chen DM. Remote sensing technology for mapping and monitoring land-cover and land-use change. Progress in Planning 2004, 61:301-325.

24. Giri C, Pengra B, Long J, Loveland TR. Next generation of global land cover characterization, mapping, and monitoring. International Journal of Applied Earth Observation and Geoinformation 2013, 25:30-37.

25. Lillesand TM, Kiefer RW, Chipman JW. Remote sensing and image interpretation. 5th ed. / Thomas M. Lillesand, Ralph W. Kiefer, Jonathan W. Chipman. ed. New York ; [Great Britain]: Wiley; 2004.

26. Morgan JL, Gergel SE, Coops NC. Aerial photography: A rapidly evolving tool for ecological management. Bioscience 2010, 60:47-59.

27. Feranec J, Jaffrain G, Soukup T, Hazeu G. Determining changes and flows in European landscapes 1990-2000 using CORINE land cover data. Applied Geography 2010, 30:19-35.

28. Bender O, Boehmer HJ, Jens D, Schumacher KP. Using GIS to analyse long-term cultural landscape change in Southern Germany. Landscape and Urban Planning 2005, 70:111-125.

29. Cousins SAO. Analysis of land-cover transitions based on 17th and 18th century cadastral maps and aerial photographs. Landscape Ecology 2001, 16:41-54.

30. Skanes HM, Bunce RGH. Directions of landscape change (1741-1993) in Virestad, Sweden characterised by multivariate analysis. Landscape and Urban Planning 1997, 38:61-75.

31. Hinderer M, Kastowski M, Kamelger A, Bartolini C, Schlunegger F. River loads and modern denudation of the Alps - A review. Earth-Science Reviews 2013, 118:11-44.

32. Geertsema M, Clague JJ, Schwab JW, Evans SG. An overview of recent large catastrophic landslides in northern British Columbia, Canada. Engineering Geology 2006, 83:120-143.

33. Metternicht G, Hurni L, Gogu R. Remote sensing of landslides: An analysis of the potential contribution to geo-spatial systems for hazard assessment in mountainous environments. Remote Sensing of Environment 2005, 98:284-303.

34. Guzzetti F, Mondini AC, Cardinali M, Fiorucci F, Santangelo M, Chang KT. Landslide inventory maps: New tools for an old problem. Earth-Science Reviews 2012, 112:42-66.

35. Tarolli P, Sofia G, Dalla Fontana GD. Geomorphic features extraction from high-resolution topography: landslide crowns and bank erosion. Natural Hazards 2012, 61:65-83.

36. Van Den Eeckhaut M, Kerle N, Poesen J, Hervas J. Object-oriented identification of forested landslides with derivatives of single pulse LiDAR data. Geomorphology 2012, 173:30-42.

37. Coe JA, Glancy PA, Whitney JW. Volumetric analysis and hydrologic characterization of a modern debris flow near Yucca Mountain, Nevada. Geomorphology 1997, 20:11-28.

38. DeLong SB, Prentice CS, Hilley GE, Ebert Y. Multitemporal ALSM change detection, sediment delivery, and process mapping at an active earthflow. Earth Surface Processes and Landforms 2012, 37:262-272.

39. Galli M, Ardizzone F, Cardinali M, Guzzetti F, Reichenbach P. Comparing landslide inventory maps. Geomorphology 2008, 94:268-289.

40. Glade T. Landslide occurrence as a response to land use change: a review of evidence from New Zealand. Catena 2003, 51:297-314.

41. Günther A, Reichenbach P, Malet J-P, Eeckhaut M, Hervás J, Dashwood C, Guzzetti F. Tierbased approaches for landslide susceptibility assessment in Europe. Landslides 2013, 10:529546. 
42. Soldati M, Corsini A, Pasuto A. Landslides and climate change in the Italian Dolomites since the Late glacial. Catena 2004, 55:141-161.

43. McCalpin J. Paleoseismology. 2nd ed. ed. London: Academic; 2009, 629.

44. Stoffel $\mathrm{M}$, Huggel $\mathrm{C}$. Effects of climate change on mass movements in mountain environments. Progress in Physical Geography 2012, 36:421-439.

45. Holm K, Bovis M, Jakob M. The landslide response of alpine basins to post-Little Ice Age glacial thinning and retreat in southwestern British Columbia. Geomorphology 2004, 57:201216.

46. Dapples F, Lotter AF, van Leeuwen JFN, van der Knaap WO, Dimitriadis S, Oswald D. Paleolimnological evidence for increased landslide activity due to forest clearing and landuse since $3600 \mathrm{cal}$ BP in the western Swiss Alps. Journal of Paleolimnology 2002, 27:239-248.

47. Borgatti L, Soldati M. Landslides as a geomorphological proxy for climate change: A record from the Dolomites (northern Italy). Geomorphology 2010, 120:56-64.

48. Tang QH, Gao HL, Lu H, Lettenmaier DP. Remote sensing: hydrology. Progress in Physical Geography 2009, 33:490-509.

49. Longobardi A, Villani P. Trend analysis of annual and seasonal rainfall time series in the Mediterranean area. International Journal of Climatology 2009, 30:1538-1546.

50. Shaw EM. Hydrology in practice. 4th ed. ed. London: Spon Press; 2011, 543.

51. Bui D, Kawamura A, Tong T, Amaguchi H, Nakagawa N. Spatio-temporal analysis of recent groundwater-level trends in the Red River Delta, Vietnam. Hydrogeology Journal 2012, 20:1635-1650.

52. WMO. Standardized precipitation index: User Guide. 2012. Available at: http://www.wamis.org/agm/pubs/SPI/WMO_1090_EN.pdf.

53. Bloomfield JP, Marchant BP. Analysis of groundwater drought building on the standardised precipitation index approach. Hydrology and Earth System Sciences 2013, 17:4769-4787.

54. Holman IP, Rivas-Casado M, Bloomfield JP, Gurdak JJ. Identifying non-stationary groundwater level response to North Atlantic ocean-atmosphere teleconnection patterns using wavelet coherence. Hydrogeology Journal 2011, 19:1269-1278.

55. Green TR, Taniguchi M, Kooi H, Gurdak JJ, Allen DM, Hiscock KM, Treidel H, Aureli A. Beneath the surface of global change: Impacts of climate change on groundwater. Journal of Hydrology 2011, 405:532-560.

56. Hiscock KM. Hydrogeology : principles and practice. Malden, Mass. ; Oxford: Blackwell; 2005.

57. Claessens L, Hopkinson C, Rastetter E, Vallino J. Effect of historical changes in land use and climate on the water budget of an urbanizing watershed. Water Resources Research 2006, 42:W03426.

58. Lave J, Avouac JP. Fluvial incision and tectonic uplift across the Himalayas of central Nepal. Journal of Geophysical Research-Solid Earth 2001, 106:26561-26591.

59. Korup O, Strom AL, Weidinger JT. Fluvial response to large rock-slope failures: Examples from the Himalayas, the Tien shan, and the southern Alps in new Zealand. Geomorphology 2006, 78:3-21.

60. Bridgland DR. The record from British Quaternary river systems within the context of global fluvial archives. Journal of Quaternary Science 2010, 25:433-446.

61. Surian N, Rinaldi M. Morphological response to river engineering and management in alluvial channels in Italy. Geomorphology 2003, 50:307-326.

62. Steinfeld CMM, Kingsford RT, Laffan SW. Semi-automated GIS techniques for detecting floodplain earthworks. Hydrological Processes 2013, 27:579-591.

63. Trimble SW. The use of historical data and artifacts in geomorphology. Progress in Physical Geography 2008, 32:3-29.

64. Grabowski RC, Gurnell AM. Using historical data in fluvial geomorphology. In: Kondolf GM, Piegay $\mathrm{H}$, eds. Tools in fluvial geomorphology: J. Wiley; In Press. 
65. Piégay $\mathrm{H}$, Peiry JL. Long profile evolution of a mountain stream in relation to gravel load management: Example of the middle Giffre River (French Alps). Environmental Management 1997, 21:909-919.

66. Rinaldi M, Simon A. Bed-level adjustments in the Arno River, central Italy. Geomorphology 1998, 22:57-71.

67. Surian N, Cisotto A. Channel adjustments, bedload transport and sediment sources in a gravel-bed river, Brenta River, Italy. Earth Surface Processes and Landforms 2007, 32:16411656.

68. Brooks AP, Brierley GJ. Geomorphic responses of lower Bega River to catchment disturbance, 1851-1926. Geomorphology 1997, 18:291-304.

69. Erskine WD. Oscillatory response versus progressive degradation of incised channels in Southeastern Australia. In: Darby SE, Simon A, eds. Incised river channels : processes, forms, engineering and management. Chichester: Wiley; 1999, 67-95.

70. Kondolf GM, Swanson ML. Channel adjustments to reservoir construction and gravel extraction along Stony Creek, California. Environmental Geology 1993, 21:256-269.

71. Pinter N, Heine RA. Hydrodynamic and morphodynamic response to river engineering documented by fixed-discharge analysis, Lower Missouri River, USA. Journal of Hydrology 2005, 302:70-91.

72. Rinaldi M. Recent channel adjustments in alluvial rivers of Tuscany, central Italy. Earth Surface Processes and Landforms 2003, 28:587-608.

73. Natural Resources Conservation Service. Sediment impact assessments (Ch. 13). 2007.

74. Dean DJ, Scott ML, Shafroth PB, Schmidt JC. Stratigraphic, sedimentologic, and dendrogeomorphic analyses of rapid floodplain formation along the Rio Grande in Big Bend National Park, Texas. Geological Society of America Bulletin 2011, 123:1908-1925.

75. Hupp CR, Rinaldi M. Riparian vegetation patterns in relation to fluvial landforms and channel evolution along selected rivers of Tuscany (Central Italy). Annals of the Association of American Geographers 2007, 97:12-30.

76. Olden JD, Poff NL. Redundancy and the choice of hydrologic indices for characterizing streamflow regimes. River Research and Applications 2003, 19:101-121.

77. Richter BD, Baumgartner JV, Powell J, Braun DP. A method for assessing hydrologic alteration within ecosystems. Conservation Biology 1996, 10:1163-1174.

78. Huh SH, Dickey DA, Meador MR, Ruhl KE. Temporal analysis of the frequency and duration of low and high streamflow: years of record needed to characterize streamflow variability. Journal of Hydrology 2005, 310:78-94.

79. Poff NL. Managing for variability to sustain freshwater ecosystems. Journal of Water Resources Planning and Management-Asce 2009, 135:1-4.

80. Bagnold RA. An approach to the sediment transport problem from general physics. USGS Professional Paper 422 1966, 37.

81. Nanson GC, Croke JC. A genetic classification of floodplains. Geomorphology 1992, 4:459486.

82. Bagnold RA. An Empirical Correlation of Bedload Transport Rates in Flumes and Natural Rivers. Proceedings of the Royal Society of London. A. Mathematical and Physical Sciences 1980, 372:453-473.

83. Gurnell A, Petts G. Trees as riparian engineers: The Tagliamento River, Italy. Earth Surface Processes and Landforms 2006, 31:1558-1574.

84. Yang CT. Unit stream power and sediment transport. Journal of the Hydraulics Division 1972, 98:1805-1826.

85. van den berg JH. Prediction of alluvial channel pattern of perennial rivers. Geomorphology 1995, 12:259-279.

86. Tarpanelli A, Barbetta S, Brocca L, Moramarco T. River discharge estimation by using altimetry data and simplified flood routing modeling. Remote Sensing 2013, 5:4145-4162. 
87. Uribelarrea D, Perez-Gonzalez A, Benito G. Channel changes in the Jararna and Tagus rivers (central Spain) over the past 500 years. Quaternary Science Reviews 2003, 22:2209-2221.

88. Gregory KJ, Lewin J, Thornes JB. Palaeohydrology in practice : a river basin analysis. Chichester: Wiley; 1987, 370.

89. Starkel L, Gregory KJ, Thornes JB. Temperate palaeohydrology : fluvial processes in the temperate zone during the last 15000 years: Wiley; 1991, 548.

90. Sidorchuk AY, Panin AV, Borisova OK. Morphology of river channels and surface runoff in the Volga River basin (East European Plain) during the Late Glacial period. Geomorphology 2009, 113:137-157.

91. Macklin MG, Lewin J. River sediments, great floods and centennial-scale Holocene climate change. Journal of Quaternary Science 2003, 18:101-105.

92. Macklin MG, Benito G, Gregory KJ, Johnstone E, Lewin J, Michczynska DJ, Soja R, Starkel L, Thomdycraft VR. Past hydrological events reflected in the Holocene fluvial record of Europe. Catena 2006, 66:145-154.

93. Caine N, Swanson FJ. Geomorphic coupling of hillslope and channel systems in two small mountain basins. Zeitschrift fur Geomorphologie 1989, 33:189-203.

94. Fryirs KA, Brierley GJ, Preston NJ, Spencer J. Catchment-scale (dis)connectivity in sediment flux in the upper Hunter catchment, New South Wales, Australia. Geomorphology 2007, 84:297-316.

95. Fryirs K. (Dis)Connectivity in catchment sediment cascades: a fresh look at the sediment delivery problem. Earth Surface Processes and Landforms 2013, 38:30-46.

96. Reid LM, Dunne T. Rapid evaluation of sediment budgets. Reiskirchen: Catena; 1996, 164.

97. Roberts RG, Church M. The sediment budget in severely disturbed watersheds, Queen Charlotte Ranges, British Columbia. Canadian Journal of Forest Research-Revue Canadienne De Recherche Forestiere 1986, 16:1092-1106.

98. Brown AG, Carey C, Erkens G, Fuchs M, Hoffmann T, Macaire JJ, Moldenhauer KM, Walling DE. From sedimentary records to sediment budgets: Multiple approaches to catchment sediment flux. Geomorphology 2009, 108:35-47.

99. Chartin C, Evrard O, Salvador-Blanes S, Hinschberger F, Van Oost K, Lefevre I, Daroussin J, Macaire JJ. Quantifying and modelling the impact of land consolidation and field borders on soil redistribution in agricultural landscapes (1954-2009). Catena 2013, 110:184-195.

100. Croke J, Todd P, Thompson C, Watson F, Denham R, Khanal G. The use of multi temporal LiDAR to assess basin-scale erosion and deposition following the catastrophic January 2011 Lockyer flood, SE Queensland, Australia. Geomorphology 2013, 184:111-126.

101. Theler D, Reynard E, Lambiel C, Bardou E. The contribution of geomorphological mapping to sediment transfer evaluation in small alpine catchments. Geomorphology 2010, 124:113123.

102. Lexartza-Artza I, Wainwright J. Making connections: changing sediment sources and sinks in an upland catchment. Earth Surface Processes and Landforms 2011, 36:1090-1104.

103. Hoffmann T, Erkens G, Gerlach R, Klostermann J, Lang A. Trends and controls of Holocene floodplain sedimentation in the Rhine catchment. Catena 2009, 77:96-106.

104. Lewin J. Medieval environmental impacts and feedbacks: The lowland floodplains of England and Wales. Geoarchaeology-an International Journal 2010, 25:267-311.

105. Macklin MG, Jones AF, Lewin J. River response to rapid Holocene environmental change: evidence and explanation in British catchments. Quaternary Science Reviews 2010, 29:15551576.

106. Walter RC, Merritts DJ. Natural streams and the legacy of water-powered mills. Science 2008, 319:299-304.

107. Brown AG. Colluvial and alluvial response to land use change in Midland England: An integrated geoarchaeological approach. Geomorphology 2009, 108:92-106. 
108. Wischmeier WH, Smith DD. Predicting rainfall-erosion losses Washington, D.C.:

USDA/Science and Education Administration, US. Govt. Printing Office; 1978, 55.

109. Renard KG, Foster GR, Weesies GA, Porter JP. RUSLE - Revise universal soil loss equation. Journal of Soil and Water Conservation 1991, 46:30-33.

110. de Vente J, Poesen J, Verstraeten G. The application of semi-quantitative methods and reservoir sedimentation rates for the prediction of basin sediment yield in Spain. Journal of Hydrology 2005, 305:63-86.

111. Sear DA, Newson MD. Environmental change in river channels: a neglected element. Towards geomorphological typologies, standards and monitoring. Science of The Total Environment 2003, 310:17-23.

112. Gurnell AM. Wood in fluvial systems. In: Shroder J, Jr., Wohl E, eds. Treatise on Geomorphology. Vol. 9. San Diego, CA, USA: Academic Press; 2013, 163-188.

113. Gurnell AM. Plants as river system engineers. Earth Surface Processes and Landforms 2014, 39:4-25.

114. Beschta RL, Ripple WJ. River channel dynamics following extirpation of wolves in northwestern Yellowstone National Park, USA. Earth Surface Processes and Landforms 2006, 31:1525-1539.

115. Kondolf GM, Piégay H. Changes in the riparian zone of the lower Eygues River, France, since 1830. Landscape Ecology 2007, 22:367-384.

116. Bertoldi W, Gurnell AM, Drake NA. The topographic signature of vegetation development along a braided river: Results of a combined analysis of airborne lidar, color air photographs, and ground measurements. Water Resources Research 2011, 47:W06525.

117. Comiti F, Da Canal M, Surian N, Mao L, Picco L, Lenzi MA. Channel adjustments and vegetation cover dynamics in a large gravel bed river over the last 200 years. Geomorphology 2011, 125:147-159.

118. Dean DJ, Schmidt JC. The role of feedback mechanisms in historic channel changes of the lower Rio Grande in the Big Bend region. Geomorphology 2011, 126:333-349.

119. Henshaw AJ, Gurnell AM, Bertoldi W, Drake NA. An assessment of the degree to which Landsat TM data can support the assessment of fluvial dynamics, as revealed by changes in vegetation extent and channel position, along a large river. Geomorphology 2013, 202:7485.

120. Antonarakis AS, Richards KS, Brasington J. Object-based land cover classification using airborne LiDAR. Remote Sensing of Environment 2008, 112:2988-2998.

121. Geerling GW, Vreeken-Buijs MJ, Jesse P, Ragas AMJ, Smits AJM. Mapping river floodplain ecotopes by segmentation of spectral (Casi) and structural (Lidar) remote sensing data. River Research and Applications 2009, 25:795-813.

122. Greco SE, Fremier AK, Larsen EW, Plant RE. A tool for tracking floodplain age land surface patterns on a large meandering river with applications for ecological planning and restoration design. Landscape and Urban Planning 2007, 81:354-373.

123. Meitzen KM. Lateral channel migration effects on riparian forest structure and composition, Congaree River, South Carolina, USA. Wetlands 2009, 29:465-475.

124. Hohensinner $\mathrm{S}$, Habersack $\mathrm{H}$, Jungwirth $\mathrm{M}$, Zauner $\mathrm{G}$. Reconstruction of the characteristics of a natural alluvial river-floodplain system and hydromorphological changes following human modifications: the Danube River (1812-1991). River Research and Applications 2004, 20:2541.

125. Hohensinner S, Jungwirth M, Muhar S, Schmutz S. Spatio-temporal habitat dynamics in a changing Danube River landscape 1812-2006. River Research and Applications 2011, 27:939955.

126. Lassettre NS, Piégay H, Dufour S, Rollet A-J. Decadal changes in distribution and frequency of wood in a free meandering river, the Ain River, France. Earth Surface Processes and Landforms 2008, 33:1098-1112. 
127. Marcus WA, Legleiter CJ, Aspinall RJ, Boardman JW, Crabtree RL. High spatial resolution hyperspectral mapping of in-stream habitats, depths, and woody debris in mountain streams. Geomorphology 2003, 55:363-380.

128. Bertoldi W, Gurnell AM, Welber M. Wood recruitment and retention: The fate of eroded trees on a braided river explored using a combination of field and remotely-sensed data sources. Geomorphology 2013, 180:146-155.

129. Fonstad MA, Dietrich JT, Courville BC, Jensen JL, Carbonneau PE. Topographic structure from motion: a new development in photogrammetric measurement. Earth Surface Processes and Landforms 2013, 38:421-430.

130. Westoby MJ, Brasington J, Glasser NF, Hambrey MJ, Reynolds JM. 'Structure-from-Motion' photogrammetry: A low-cost, effective tool for geoscience applications. Geomorphology 2012, 179:300-314.

131. Maser C, Sedell JR. From the forest to the sea : the ecology of wood in streams, rivers, estuaries, and oceans. Delray Beach, FL: St. Lucie Press; 1994, 200.

132. Lawler DM. The measurement of river bank erosion and lateral channel change - a review. Earth Surface Processes and Landforms 1993, 18:777-821.

133. Gurnell AM, Downward SR, Jones R. Channel planform change on the River Dee meanders, 1876-1992. Regulated Rivers-Research \& Management 1994, 9:187-204.

134. Gurnell AM. Channel change on the River Dee meanders, 1946-1992, from the analysis of air photographs. Regulated Rivers-Research \& Management 1997, 13:13-26.

135. Hooke JM. Cutoffs galore!: occurrence and causes of multiple cutoffs on a meandering river. Geomorphology 2004, 61:225-238.

136. Hooke JM. Spatial variability, mechanisms and propagation of change in an active meandering river. Geomorphology 2007, 84:277-296.

137. Surian N. Channel changes due to river regulation: The case of the Piave River, Italy. Earth Surface Processes and Landforms 1999, 24:1135-1151.

138. Surian N, Ziliani L, Comiti F, Lenzi MA, Mao L. Channel adjustments and alteration of sediment fluxes in gravel-bed rivers of North-eastern Italy: Potentials and limitations for channel recovery. River Research and Applications 2009, 25:551-567.

139. Ziliani L, Surian N. Evolutionary trajectory of channel morphology and controlling factors in a large gravel-bed river. Geomorphology 2012, 173-174:104-117.

140. Yao Z, Ta W, Jia X, Xiao J. Bank erosion and accretion along the Ningxia-Inner Mongolia reaches of the Yellow River from 1958 to 2008. Geomorphology 2011, 127:99-106.

141. Gupta N, Atkinson PM, Carling PA. Decadal length changes in the fluvial planform of the River Ganga: bringing a mega-river to life with Landsat archives. Remote Sensing Letters 2013, 4:1-9.

142. Mount NJ, Tate NJ, Sarker MH, Thorne CR. Evolutionary, multi-scale analysis of river bank line retreat using continuous wavelet transforms: Jamuna River, Bangladesh. Geomorphology 2013, 183:82-95.

143. Pavelsky TM, Smith LC. RivWidth: A software tool for the calculation of river widths from remotely sensed imagery. leee Geoscience and Remote Sensing Letters 2008, 5:70-73.

144. Rouse JC, Hass RH, Schell JA, Deering DW, Harlan JC. Monitoring the vernal advancement and retrogradation (greenwave effect) of natural vegetation NASA / Texas A\&M University Report 1974.

145. Xu HQ. Modification of normalised difference water index (NDWI) to enhance open water features in remotely sensed imagery. International Journal of Remote Sensing 2006, 27:3025-3033.

146. Zanoni L, Gurnell A, Drake N, Surian N. Island dynamics in a braided river from analysis of historical maps and air photographs. River Research and Applications 2008, 24:1141-1159. 
147. Latrubesse EM, Amsler ML, de Morais RP, Aquino S. The geomorphologic response of a large pristine alluvial river to tremendous deforestation in the South American tropics: The case of the Araguaia River. Geomorphology 2009, 113:239-252.

148. Hooke JM, Yorke L. Channel bar dynamics on multi-decadal timescales in an active meandering river. Earth Surface Processes and Landforms 2011, 36:1910-1928.

149. White JQ, Pasternack GB, Moir HJ. Valley width variation influences riffle-pool location and persistence on a rapidly incising gravel-bed river. Geomorphology 2010, 121:206-221.

150. Gurnell AM. Vegetation along river corridors: hydrogeomorphological interactions. In: Gurnell AM, Petts GE, eds. Changing river channels. Chichester, UK: Wiley; 1995.

151. Hupp $C R$, Bornette $G$. Vegetation as a tool in the interpretation of fluvial geomorphic processes and landforms in humid temperate areas. In: Kondolf GM, Piegay H, eds. Tools in fluvial geomorphology. Chichester: J. Wiley; 2003, 269-288.

152. Perucca E, Camporeale C, Ridolfi L. Influence of river meandering dynamics on riparian vegetation pattern formation. Journal of Geophysical Research-Biogeosciences 2006, 111: G01001.

153. Perucca E, Camporeale C, Ridolfi L. Significance of the riparian vegetation dynamics on meandering river morphodynamics. Water Resources Research 2007, 43:W03430.

154. Page K, Nanson G. Concave-bank benches and associated floodplain formation. Earth Surface Processes and Landforms 1982, 7:529-543.

155. Salo J, Kalliola R, Hakkinen I, Makinen Y, Niemela P, Puhakka M, Coley PD. River dynamics and the diversity of amazon lowland forest. Nature 1986, 322:254-258.

156. Hupp CR, Osterkamp WR. Riparian vegetation and fluvial geomorphic processes. Geomorphology 1996, 14:277-295.

157. Toledo ZO, Kauffman JB. Root biomass in relation to channel morphology of headwater streams. Journal of the American Water Resources Association 2001, 37:1653-1663.

158. Hoyle J, Brooks A, Brierley G, Fryirs K, Lander J. Spatial variability in the timing, nature and extent of channel response to typical human disturbance along the Upper Hunter River, New South Wales, Australia. Earth Surface Processes and Landforms 2008, 33:868-889.

159. Brown AG, Toms PS, Carey CJ, Howard AJ, Challis K. Late Pleistocene-Holocene river dynamics at the Trent-Soar confluence, England, UK. Earth Surface Processes and Landforms 2013, 38:237-249.

160. Wheaton JM, Brasington J, Darby SE, Sear DA. Accounting for uncertainty in DEMs from repeat topographic surveys: improved sediment budgets. Earth Surface Processes and Landforms 2010, 35:136-156.

161. Moretto J, Rigon E, Mao L, Picco L, Delai F, Lenzi MA. Channel adjustments and island dynamics in the Brenta River (Italy) over the last 30 years. River Research and Applications 2013. doi: 10.1002/rra.

162. Lane SN, Widdison PE, Thomas RE, Ashworth PJ, Best JL, Lunt IA, Smith GHS, Simpson CJ. Quantification of braided river channel change using archival digital image analysis. Earth Surface Processes and Landforms 2010, 35:971-985.

163. Lane SN, Westaway RM, Murray Hicks D. Estimation of erosion and deposition volumes in a large, gravel-bed, braided river using synoptic remote sensing. Earth Surface Processes and Landforms 2003, 28:249-271.

164. Westaway RM, Lane SN, Hicks DM. Airborne remote sensing of clear water, shallow, gravelbed rivers using digital photogrammetry and image analysis. Photogrammetric Engineering and Remote Sensing 2000, 67:1271-1281.

165. O'Neal MA, Pizzuto JE. The rates and spatial patterns of annual riverbank erosion revealed through terrestrial laser-scanner surveys of the South River, Virginia. Earth Surface Processes and Landforms 2011, 36:695-701.

166. De Rose RC, Basher LR. Measurement of river bank and cliff erosion from sequential LIDAR and historical aerial photography. Geomorphology 2011, 126:132-147. 
167. Passalacqua P, Do Trung T, Foufoula-Georgiou E, Sapiro G, Dietrich WE. A geometric framework for channel network extraction from lidar: Nonlinear diffusion and geodesic paths. Journal of Geophysical Research-Earth Surface 2010, 115: F01002.

168. Passalacqua $P$, Belmont $P$, Foufoula-Georgiou E. Automatic geomorphic feature extraction from lidar in flat and engineered landscapes. Water Resources Research 2012, 48:W03528.

169. Fisher GB, Bookhagen B, Amos CB. Channel planform geometry and slopes from freely available high-spatial resolution imagery and DEM fusion: Implications for channel width scalings, erosion proxies, and fluvial signatures in tectonically active landscapes. Geomorphology 2013, 194:46-56.

170. Hilldale RC, Raff D. Assessing the ability of airborne LiDAR to map river bathymetry. Earth Surface Processes and Landforms 2008, 33:773-783.

171. Gao J. Bathymetric mapping by means of remote sensing: methods, accuracy and limitations. Progress in Physical Geography 2009, 33:103-116.

172. Carling, Gölz, Orr, Radecki P. The morphodynamics of fluvial sand dunes in the River Rhine, near Mainz, Germany. I. Sedimentology and morphology. Sedimentology 2000, 47:227-252.

173. Schmitt T, Mitchell NC, Ramsay ATS. Characterizing uncertainties for quantifying bathymetry change between time-separated multibeam echo-sounder surveys. Continental Shelf Research 2008, 28:1166-1176.

174. Cserkesz-Nagy A, Toth T, Vajk O, Sztano O. Erosional scours and meander development in response to river engineering: middle Tisza region, Hungary. Proceedings of the Geologists Association 2010, 121:238-247.

175. Winterbottom SJ, Gilvear DJ. Quantification of channel bed morphology in gravel-bed rivers using airborne multispectral imagery and aerial photography. Regulated Rivers: Research \& Management 1997, 13:489-499.

176. Carbonneau PE, Lane SN, Bergeron N. Feature based image processing methods applied to bathymetric measurements from airborne remote sensing in fluvial environments. Earth Surface Processes and Landforms 2006, 31:1413-1423.

177. Legleiter CJ. Mapping river depth from publicly available aerial images. River Research and Applications 2013, 29:760-780.

178. Roberts ACB. Shallow water bathymetry using integrated airborne multi-spectral remote sensing. International Journal of Remote Sensing 1999, 20:497-510.

179. Whited D, Stanford JA, Kimball JS. Application of airborne multispectral digital imagery to quantify riverine habitats at different base flows. River Research and Applications 2002, 18:583-594.

180. Legleiter CJ, Overstreet BT. Mapping gravel bed river bathymetry from space. Journal of Geophysical Research-Earth Surface 2012, 117:F04024.

181. Legleiter CJ, Roberts DA, Lawrence RL. Spectrally based remote sensing of river bathymetry. Earth Surface Processes and Landforms 2009, 34:1039-1059.

182. Rickenmann D, Turowski JM, Fritschi B, Klaiber A, Ludwig A. Bedload transport measurements at the Erlenbach stream with geophones and automated basket samplers. Earth Surface Processes and Landforms 2012, 37:1000-1011.

183. Chen Z, Li J, Shen H, Zhanghua W. Yangtze River of China: historical analysis of discharge variability and sediment flux. Geomorphology 2001, 41:77-91.

184. Boix-Fayos C, Barbera GG, Lopez-Bermudez F, Castillo VM. Effects of check dams, reforestation and land-use changes on river channel morphology: Case study of the Rogativa catchment (Murcia, Spain). Geomorphology 2007, 91:103-123.

185. Martin-Vide JP, Ferrer-Boix C, Ollero A. Incision due to gravel mining: Modeling a case study from the Gallego River, Spain. Geomorphology 2010, 117:261-271.

186. Wishart D, Warburton J, Bracken L. Gravel extraction and planform change in a wandering gravel-bed river: The River Wear, Northern England. Geomorphology 2008, 94:131-152. 
187. Ham DG, Church M. Bed-material transport estimated from channel morphodynamics: Chilliwack River, British Columbia. Earth Surface Processes and Landforms 2000, 25:11231142.

188. Ritchie JC, Zimba PV, Everitt JH. Remote sensing techniques to assess water quality. Photogrammetric Engineering and Remote Sensing 2003, 69:695-704.

189. Kilham NE, Roberts $D$, Singer MB. Remote sensing of suspended sediment concentration during turbid flood conditions on the Feather River, California-A modeling approach. Water Resources Research 2012, 48:W01521.

190. Ashmore PE, Church M. Sediment transport and river morphology: a paradigm for study. In: Klingeman PC, Beschta RL, Komar PD, Bradley JB, eds. Gravel-bed rivers in the environment. Highlands Ranch, CO: Water Resources Publications; 1998, 115-148.

191. Martin Y, Church M. Bed-material transport estimated from channel surveys - Vedder River, British-Columbia. Earth Surface Processes and Landforms 1995, 20:347-361.

192. McLean DG, Church M. Sediment transport along lower Fraser River - 2. Estimates based on the long-term gravel budget. Water Resources Research 1999, 35:2549-2559.

193. Hicks DM, Gomez B. Sediment transport. In: Kondolf GM, Piegay H, eds. Tools in fluvial geomorphology. Chichester: J. Wiley; 2003, 425-461.

194. Brasington J, Langham J, Rumsby B. Methodological sensitivity of morphometric estimates of coarse fluvial sediment transport. Geomorphology 2003, 53:299-316.

195. Ibbeken H, Schleyer R. Photo-sieving: A method for grain-size analysis of coarse-grained, unconsolidated bedding surfaces. Earth Surface Processes and Landforms 1986, 11:59-77.

196. Butler JB, Lane SN, Chandler JH. Automated extraction of grain-size data from gravel surfaces using digital image processing. Journal of Hydraulic Research 2001, 39:519-529.

197. Carbonneau PE, Lane SN, Bergeron NE. Catchment-scale mapping of surface grain size in gravel bed rivers using airborne digital imagery. Water Resources Research 2004, 40:W07202.

198. Carbonneau PE, Bergeron N, Lane SN. Automated grain size measurements from airborne remote sensing for long profile measurements of fluvial grain sizes. Water Resources Research 2005, 41:W11426.

199. Dugdale SJ, Carbonneau PE, Campbell D. Aerial photosieving of exposed gravel bars for the rapid calibration of airborne grain size maps. Earth Surface Processes and Landforms 2010, 35:627-639.

200. Buscombe D, Rubin DM, Warrick JA. A universal approximation of grain size from images of noncohesive sediment. Journal of Geophysical Research-Earth Surface 2010, 115:F02015.

201. Tucci M, Giordano A. Positional accuracy, positional uncertainty, and feature change detection in historical maps: Results of an experiment. Computers, Environment and Urban Systems 2011, 35:452-463.

202. Bolstad PV, Smith JL. Errors in GIS. Journal of Forestry 1992, 90:21-29.

203. Gurnell AM, Peiry J-L, Petts GE. Using historical data in fluvial geomorphology. In: Kondolf GM, Piegay H, eds. Tools in fluvial geomorphology. Chichester: J. Wiley; 2003, 77-101.

204. Perez-Hoyos A, Garcia-Haro FJ, San-Miguel-Ayanz J. Conventional and fuzzy comparisons of large scale land cover products: Application to CORINE, GLC2000, MODIS and GlobCover in Europe. Isprs Journal of Photogrammetry and Remote Sensing 2012, 74:185-201.

205. Hooke JM, Kain RJP. Historical change in the physical environment : a guide to sources and techniques. London: Butterworth Scientific; 1982, 236.

206. Jensen JR. Remote sensing of the environment : an earth resource perspective. Upper Saddle River, N.J.: Prentice Hall ; London : Prentice-Hall International; 2000, 544.

207. Hu B. Application of geographic information systems(GIS) in the history of cartography. World Academy of Science, Engineering and Technology 2010, 42:185-189. 
208. Manzano-Agugliaro F, San-Antonio-Gómez C, López S, Montoya FG, Gil C. Pareto-based evolutionary algorithms for the calculation of transformation parameters and accuracy assessment of historical maps. Computers \& Geosciences 2013, 57:124-132.

209. James LA, Hodgson ME, Ghoshal S, Latiolais MM. Geomorphic change detection using historic maps and DEM differencing: The temporal dimension of geospatial analysis. Geomorphology 2012, 137:181-198.

210. Mount N, Louis J. Estimation and propagation of error in measurements of river channel movement from aerial imagery. Earth Surface Processes and Landforms 2005, 30:635-643.

211. Lu D, Mausel P, Brondizio E, Moran E. Change detection techniques. International Journal of Remote Sensing 2004, 25:2365-2407.

212. Congalton RG, Green K. Assessing the accuracy of remotely sensed data : principles and practices. 2nd ed. Boca Raton: CRC Press/Taylor \& Francis; 2009, 200.

213. Congalton RG. A review of assessing the accuracy of classifications of remotely sensed data. Remote Sensing of Environment 1991, 37:35-46.

214. Fichera CR, Modica G, Pollino M. Land cover classification and change-detection analysis using multi-temporal remote sensed imagery and landscape metrics. European Journal of Remote Sensing 2012, 45:1-18.

215. Metternicht $\mathrm{G}$. Change detection assessment using fuzzy sets and remotely sensed data: an application of topographic map revision. Isprs Journal of Photogrammetry and Remote Sensing 1999, 54:221-233.

216. Milan DJ, Heritage GL, Large ARG, Fuller IC. Filtering spatial error from DEMs: Implications for morphological change estimation. Geomorphology 2011, 125:160-171.

217. Jordan BA, Annable WK, Watson CC, Sen D. Contrasting stream stability characteristics in adjacent urban watersheds: Santa Clara Valley, California. River Research and Applications 2010, 26:1281-1297.

218. Richter BD, Thomas GA. Restoring environmental flows by modifying dam operations. Ecology and Society 2007, 12:1 [online] URL: http://www.ecologyandsociety.org/vol12/iss11/art12/.

219. Fryirs KA, Brierley GJ. Geomorphic analysis of river systems: An approach to reading the landscape: Wiley-Blackwell; 2013.

220. Cluer B, Thorne C. A stream model evolution integrating habitat and ecosystem benefits. River Research and Applications 2014, 30:135-154.

221. Schumm AS, Harvey MD, Watson CC. Incised channel: Morphology, dynamics and control. Littleton, CO, USA.: Water Resources Publications; 1984, 200.

222. Simon A, Hupp CR. Geomorphic and vegetative recovery processes along modified Tennessee streams: an interdisciplinary approach to disturbed systems. Forest Hydrology and Watershed Managment 1986, IAHS-AISH Publ. 167.

223. Thorne CR. Channel types and morphological classifications. In: Hey RD, Thorne CR, Newson MD, eds. Applied fluvial geomorphology for river engineering and management. Chichester: Wiley; 1997.

224. Nicholas A. Morphodynamic diversity of the world's largest rivers. Geology 2013, 41:475478.

225. Ziliani L, Surian N, Coulthard TJ, Tarantola S. Reduced-complexity modeling of braided rivers: Assessing model performance by sensitivity analysis, calibration, and validation. Journal of Geophysical Research-Earth Surface 2013, 118:2243-2262.

226. Ibisate A, Díaz E, Ollero A, Acín V, Granado D. Channel response to multiple damming in a meandering river, middle and lower Aragón River (Spain). Hydrobiologia 2013, 712:5-23. 


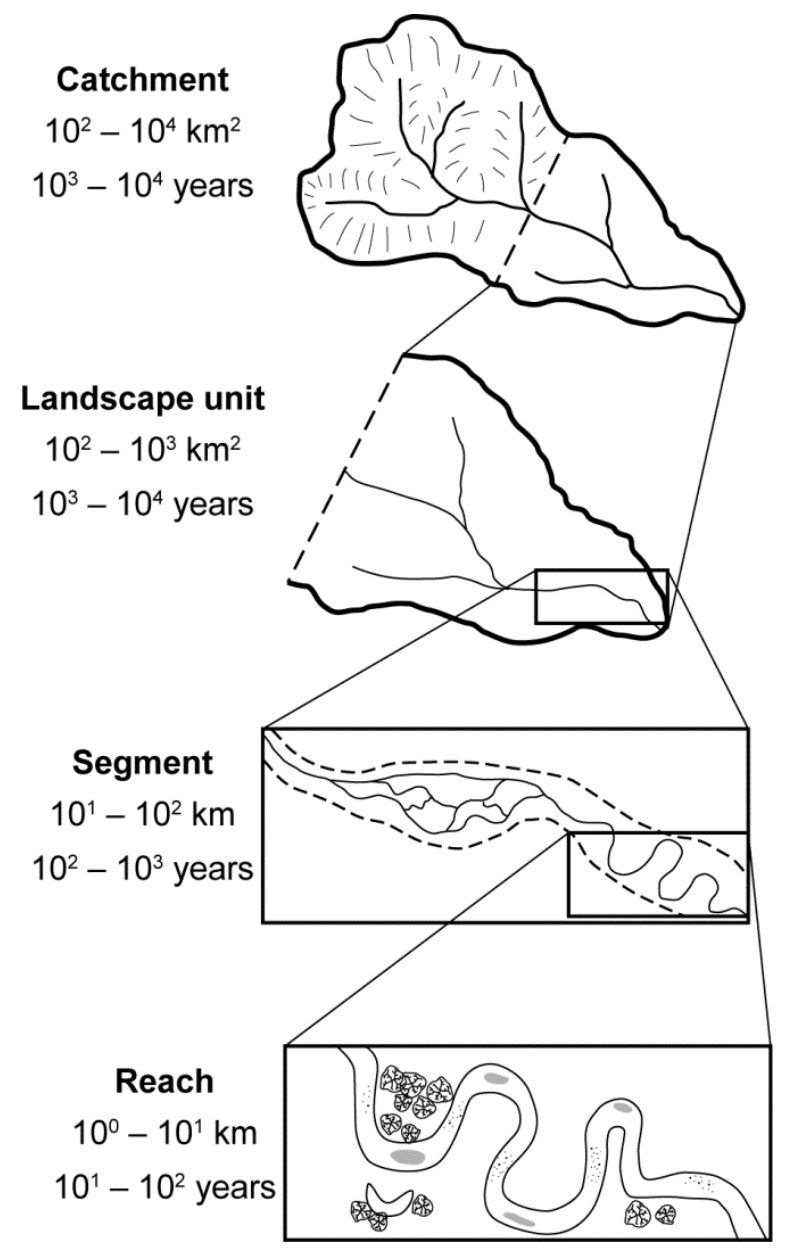

Figure 1 Hierarchy of spatial scales for the assessment of river geomorphology with indicative spatial and time scales.

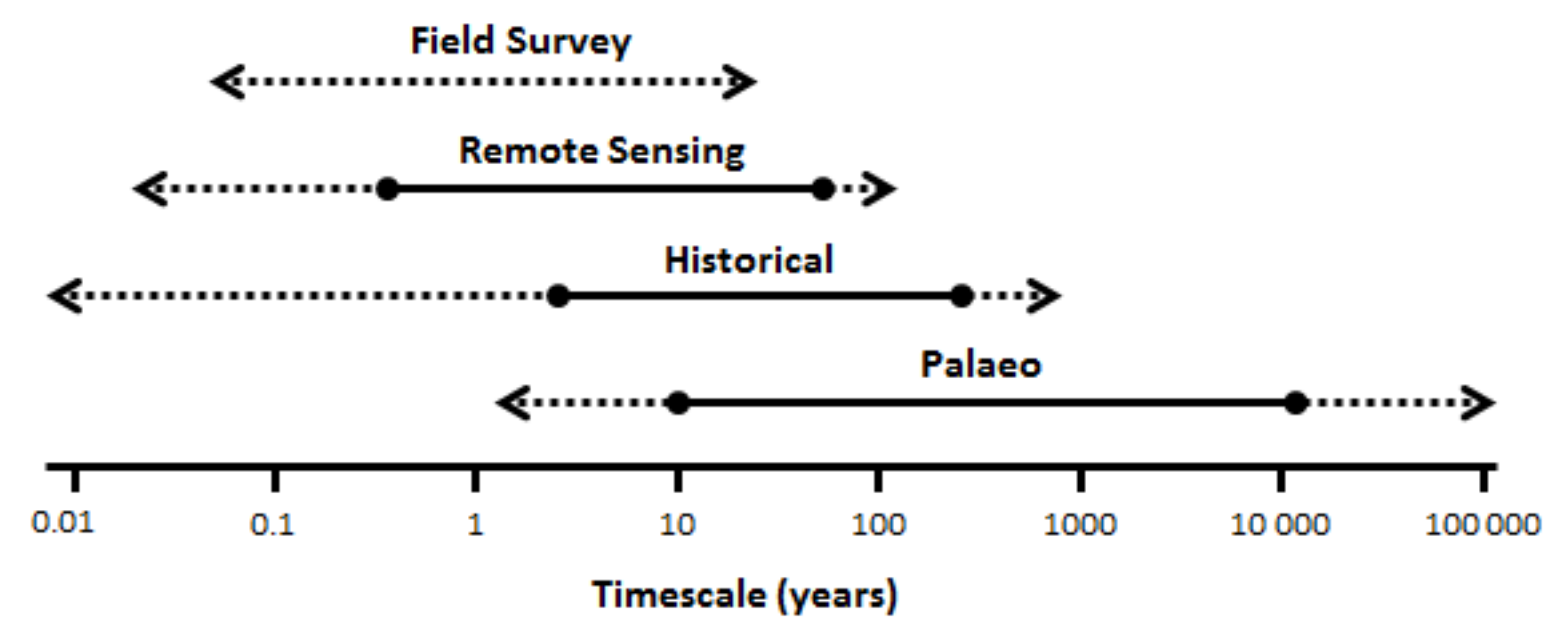

Figure 2 Temporal scales over which different approaches may yield useful information (solid lines are the core temporal scales, dashed lines illustrate the potential range of temporal scales). 


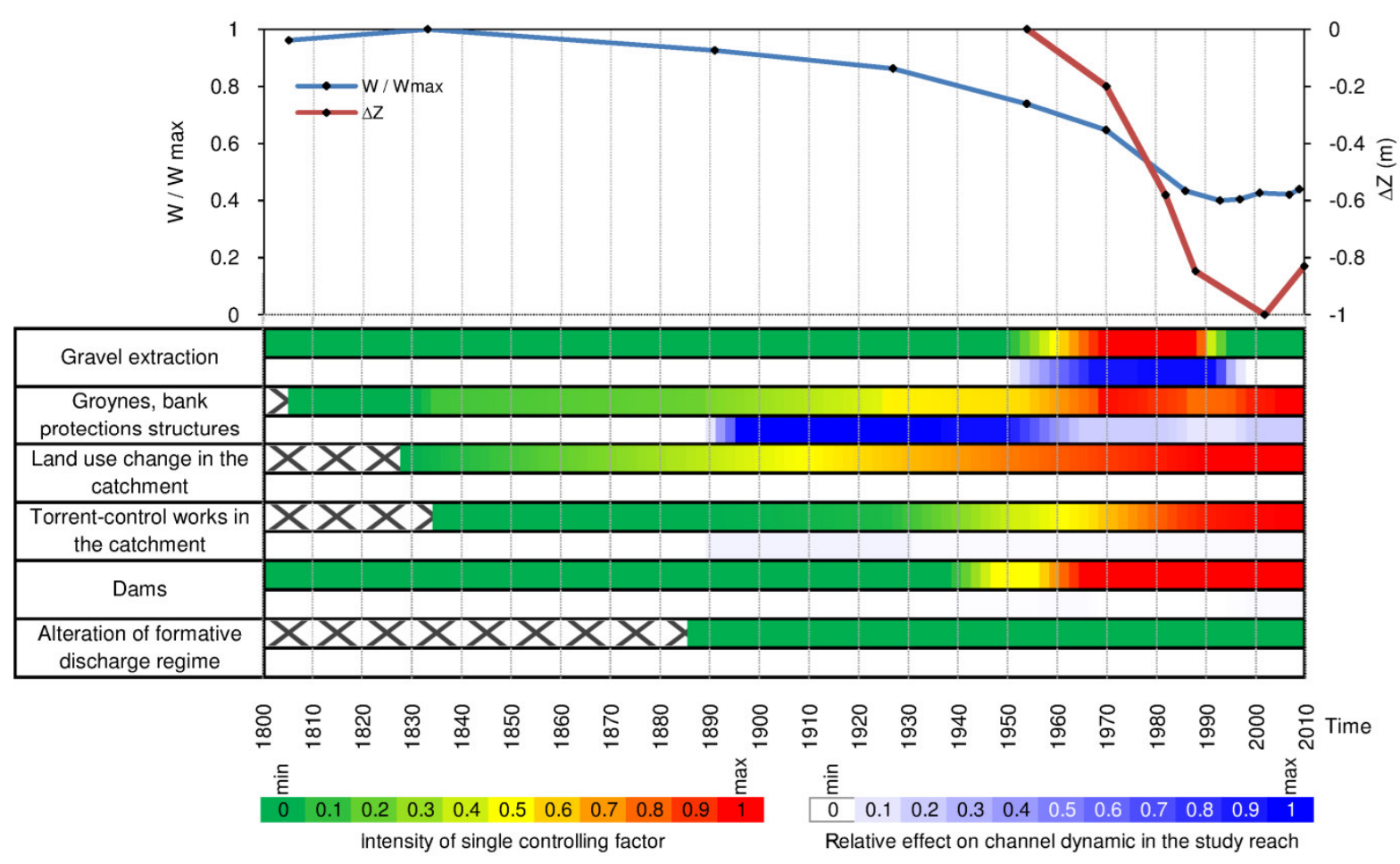

Figure 3 A chronology is a valuable tool to integrate data sources, track changes in hydrological and geomorphological characteristics over time and explore causal linkages. An example from the Tagliamento River that explores the impact of pressures on channel width (dimensionless, $W / W_{\max }$ ) and bed level (Reproduced with permission from Elsevier ${ }^{139}$ ). 


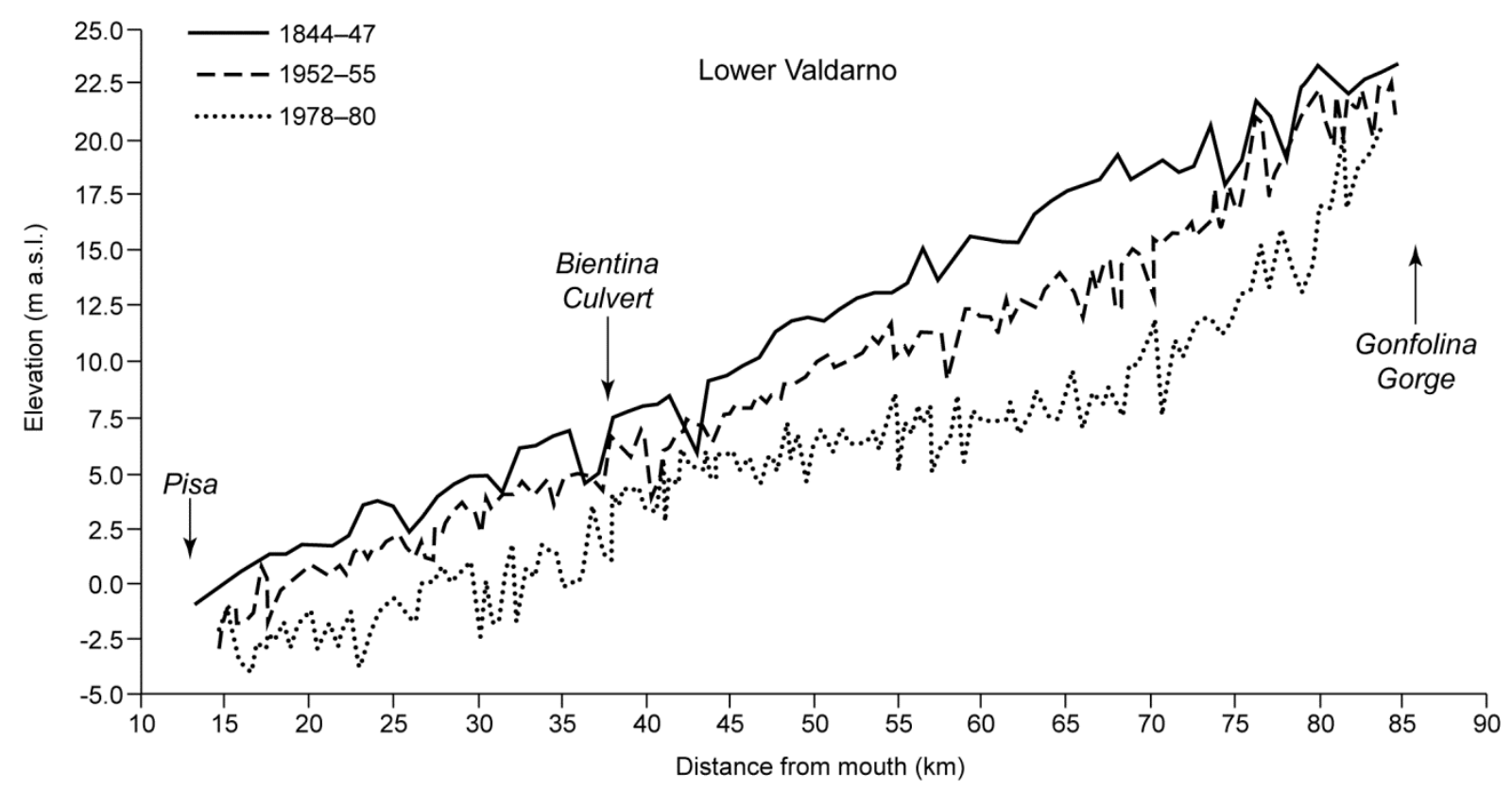

Figure 4 Changes in bed level over time for the Arno River, Italy (Modified with permission from Elsevier $\left.{ }^{66}\right)$. 

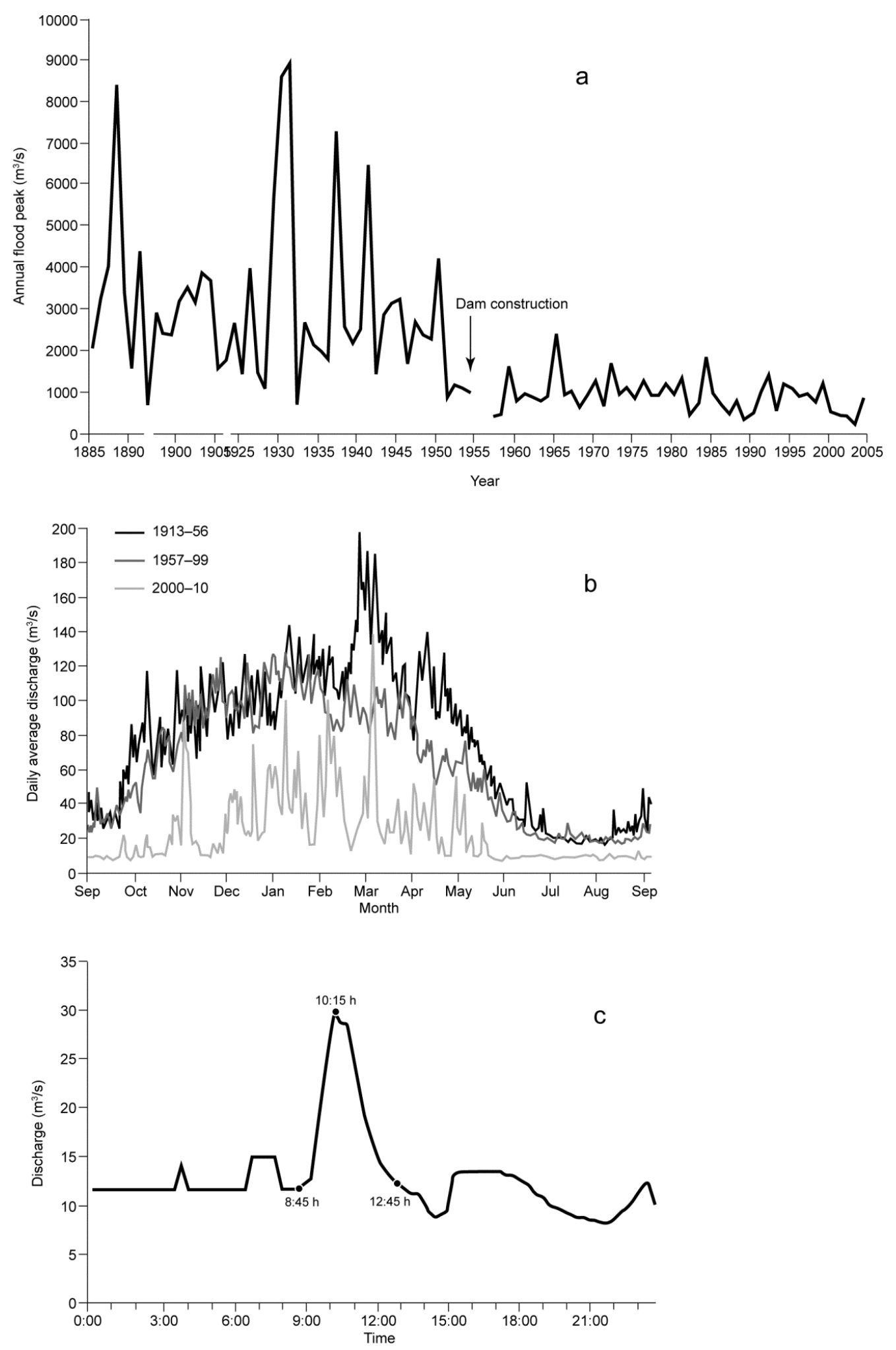

Figure 5 Alteration of flow regime caused by dam construction and operation. (a) Annual floods on the Savannah River (USA), pre- and post-construction of the Thurmond Dam in 1942 (Modified with permission from the author ${ }^{218}$ ) (b) Changes to the annual hydrograph caused by construction of successive dams, and (c)changes to daily flows (i.e. hydropeaking) as a result of dam operation on the Aragón River (Spain) (Modified with permission from Springer ${ }^{226}$ ). 


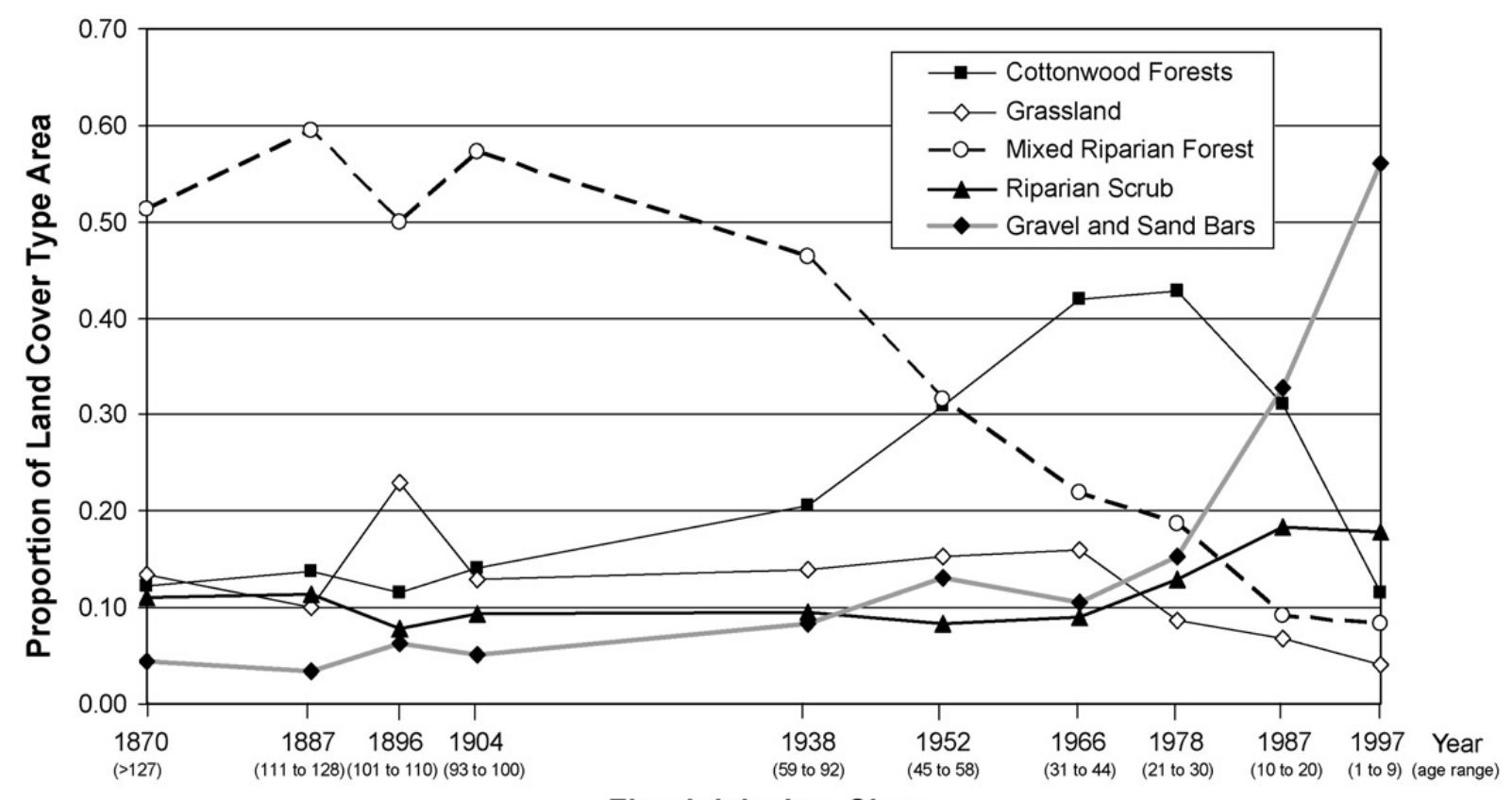

Floodplain Age Class

Figure 6 Floodplain age and vegetation community in the Sacramento River. Floodplain age was determined from a historical analysis of planform changes using historical maps and aerial photographs. Note the shift from gravel bars to cottonwood forest to mixed riparian forest with increasing floodplain age (Reproduced with permission from Elsevier ${ }^{122}$ ). 


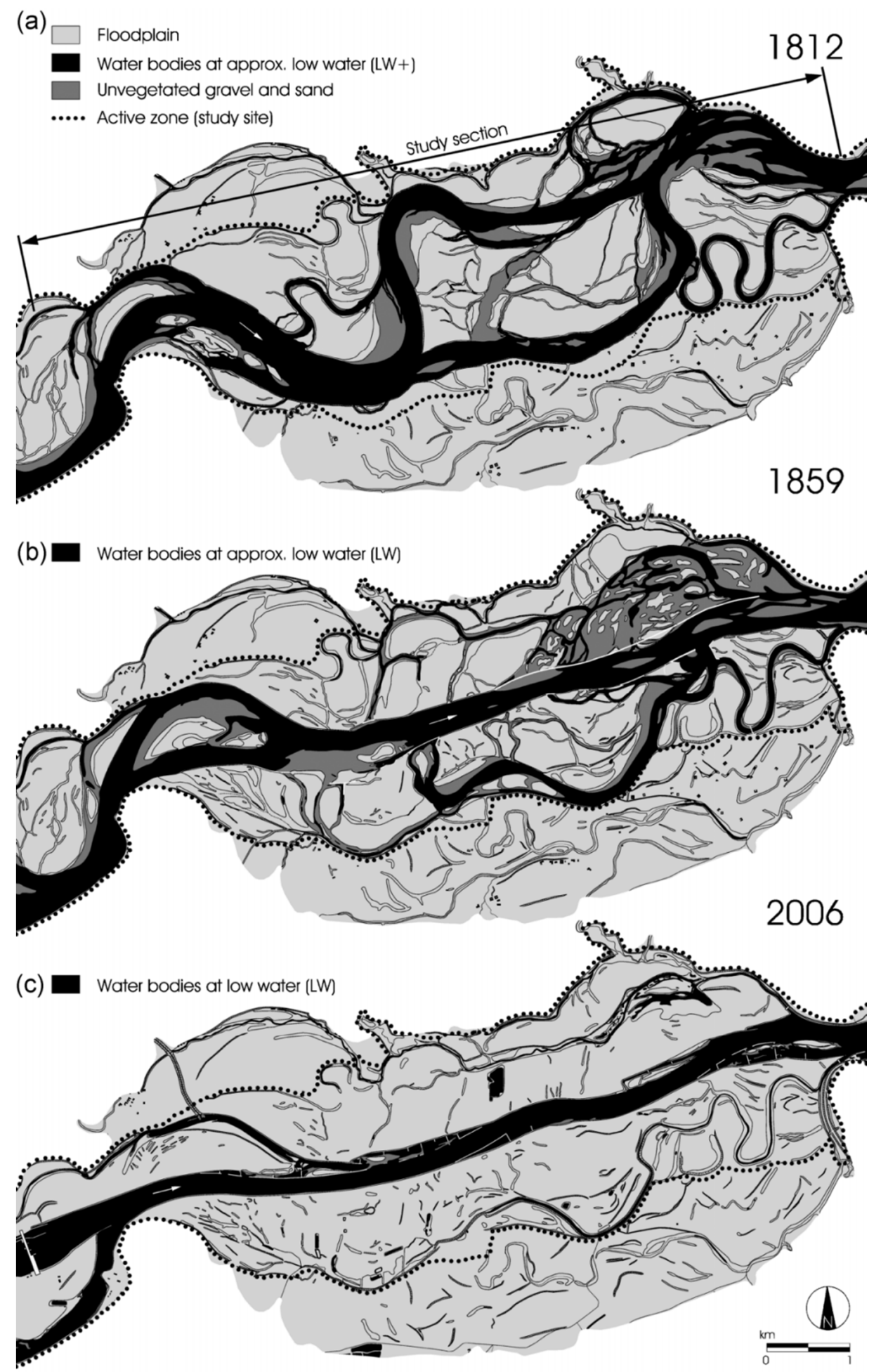

Figure 7 An analysis of historical maps reveal significant anthropogenic alterations to the Danube River that have impacted its planform and the presence of geomorphic features within the channel and floodplain. (a) The Danube 'riverscape' prior to significant human alteration (1812), after an intensive channelisation period (1859) and after the construction of a hydropower plant and further chanelisation (2006) (Reproduced with permission from Wiley ${ }^{125}$ ). 


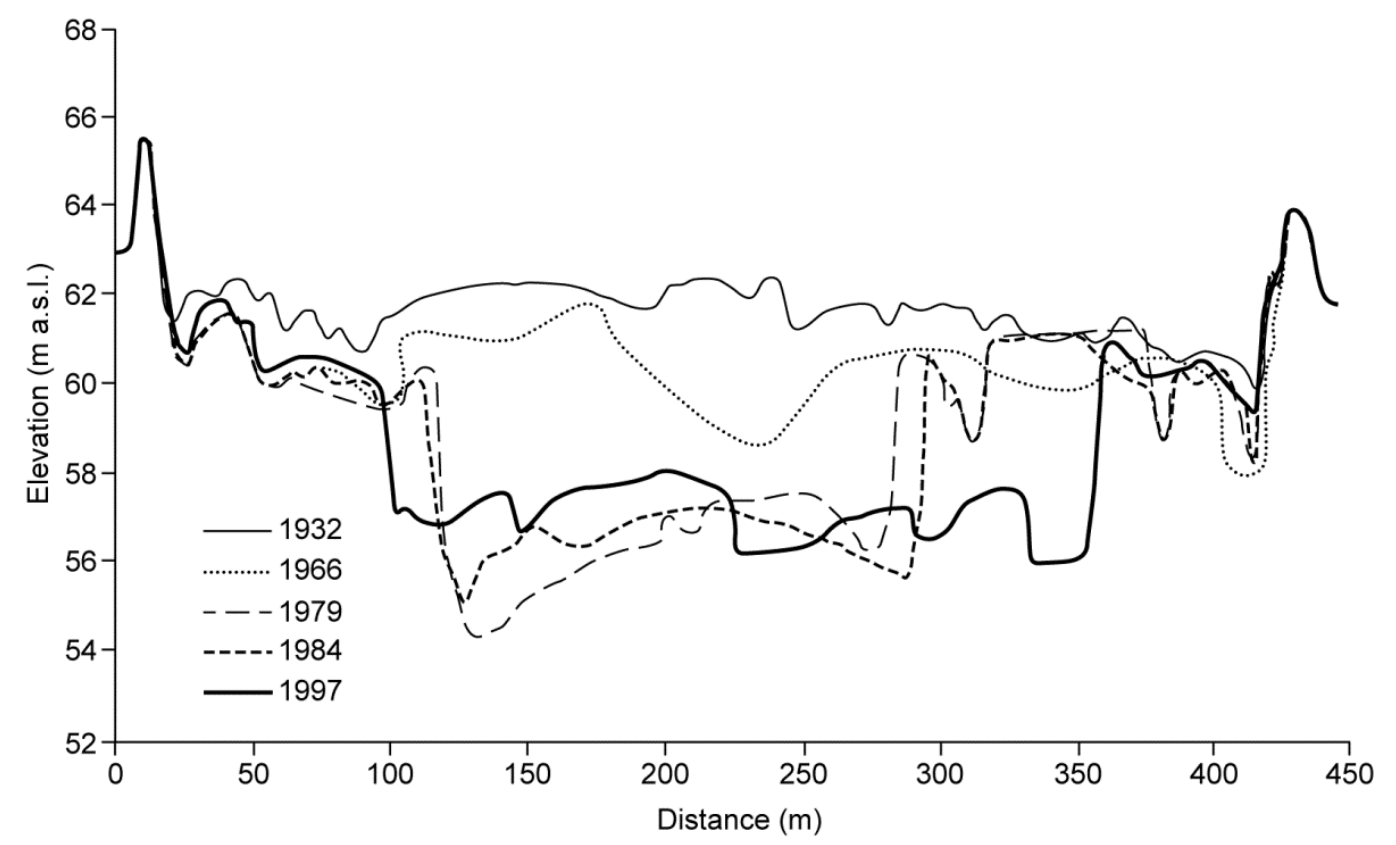

Figure 8 Temporal changes in cross-section form and bed level for a reach in the Brenta River, Italy (1932-1997) (Modified with permission from Wiley ${ }^{67}$ ).

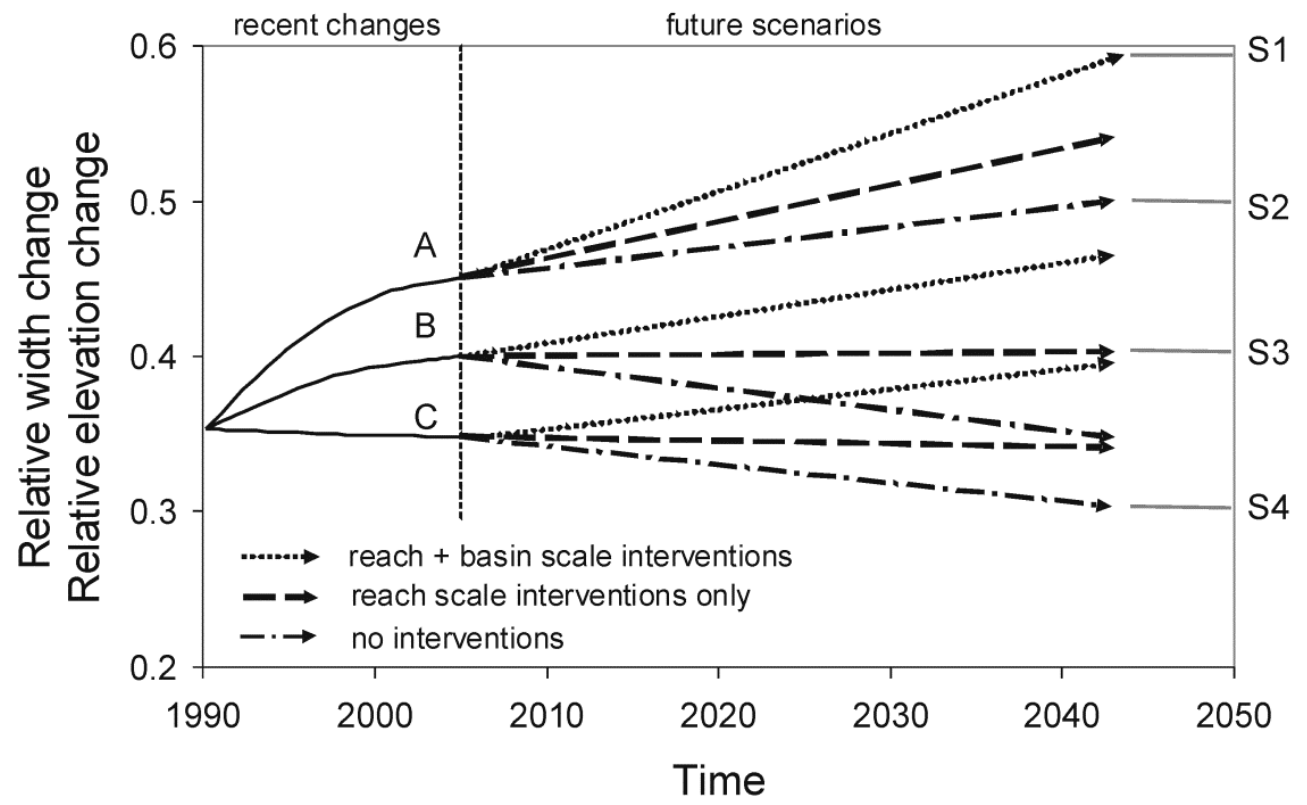

Figure 9 Possible evolutionary trajectories for the (A) upper Piave, (B) lower Brenta and (C) Cellina rivers (Italy) based on different sediment management strategies (no interventions, reach scale interventions, or reach + basin scale interventions) (Reproduced with permission from Wiley ${ }^{138}$ ). 
Tables

Table 1 Temporal change is investigated at different spatial scales.

\begin{tabular}{|c|c|}
\hline Spatial Scale & Characteristics \\
\hline \multirow[t]{2}{*}{ Catchment } & Land cover / use \\
\hline & Land topography \\
\hline \multirow[t]{3}{*}{ Landscape unit } & Land cover / use and sediment production \\
\hline & Land topography and sediment production \\
\hline & Rainfall and groundwater \\
\hline \multirow[t]{5}{*}{ Segment } & Valley setting \\
\hline & Channel gradient \\
\hline & River flows and levels \\
\hline & Sediment delivery \\
\hline & Riparian corridor and wood production \\
\hline \multirow[t]{4}{*}{ Reach } & Channel planform, migration and features \\
\hline & Channel geometry \\
\hline & Sediment transport \\
\hline & Riparian vegetation, aquatic vegetation, wood \\
\hline
\end{tabular}


Table 2 Four approaches to investigate temporal change in fluvial geomorphology

\begin{tabular}{|c|c|c|c|}
\hline $\begin{array}{l}\text { Approach } \\
\text { (Timescale) }\end{array}$ & Methods / Data sources & Strengths & Weaknesses \\
\hline $\begin{array}{l}\text { Field survey } \\
(n / a)\end{array}$ & $\begin{array}{l}\text { - River reconnaissance } \\
\text { - Morphological quality index (MQI) } \\
\text { - River Styles Framework }\end{array}$ & $\begin{array}{l}\text { - Quick and relatively inexpensive to conduct } \\
\text { - Detailed information on current channel / } \\
\text { floodplain forms and processes } \\
\text { - Essential for reach scale analysis if data are } \\
\text { unavailable from other approaches }\end{array}$ & $\begin{array}{l}\text { - Only applicable at the reach scale } \\
\text { - Can only indicate possible change } \\
\text { - Cannot estimate rates of change } \\
\text { - Requires an experienced geomorphologist }\end{array}$ \\
\hline $\begin{array}{l}\text { Remote sensing } \\
\text { (Decades) }\end{array}$ & $\begin{array}{l}\text { - Platforms: satellite, airplane, } \\
\text { remotely-operated vehicles (kites, } \\
\text { drones) } \\
\text { - Data: photography, multi- / } \\
\text { hyperspectral, altimetry (radar, } \\
\text { light detection and ranging - } \\
\text { LiDAR, terrestrial laser scanning, } \\
\text { TLS) }\end{array}$ & $\begin{array}{l}\text { - Large variety of data types that are suitable } \\
\text { for most characteristics at all spatial scales } \\
\text { - Aerial photography archives extend back up } \\
\text { to } 100 \text { years } \\
\text { - Satellite data extends back up to } 30 \text { years, } \\
\text { and has high temporal frequency }\end{array}$ & $\begin{array}{l}\text { - Most freely-available multispectral satellite } \\
\text { data has a low spatial resolution, so only } \\
\text { suitable for large spatial scales or for large, } \\
\text { wide rivers at the reach scale } \\
\text { - High resolution photography and } \\
\text { multispectral data good for segment and } \\
\text { reach scale, but are expensive to purchase / } \\
\text { commission. } \\
\text { Data processing and interpretation requires } \\
\text { specialist knowledge }\end{array}$ \\
\hline $\begin{array}{l}\text { Historical } \\
\text { (Centuries) }\end{array}$ & $\begin{array}{l}\text { - Maps } \\
\text { - Land / tax surveys } \\
\text { - Agricultural censuses } \\
\text { - River topographic surveys } \\
\text { - Monitoring station records } \\
\text { - Documentary evidence (diaries, } \\
\text { - deeds, estate records, etc) } \\
\text { - Photography, paintings, etc. }\end{array}$ & $\begin{array}{l}\text { - Historical maps can extend the timescale of } \\
\text { analysis to centuries, and be used to study } \\
\text { many characteristics } \\
\text { - Topographic surveys and gauging station } \\
\text { records are often the only data sources for } \\
\text { bed level changes. } \\
\text { - Documentary evidence can corroborate } \\
\text { evidence from other data sources }\end{array}$ & $\begin{array}{l}\text { - Information is captured and interpreted } \\
\text { through the 'lens' of the observer } \\
\text { - Availability and reliability of sources is highly } \\
\text { variable, and both generally decrease as the } \\
\text { analysis is extended further back in time } \\
\text { - Scale and original purpose of a map limits its } \\
\text { application }\end{array}$ \\
\hline
\end{tabular}




\begin{tabular}{|c|c|c|c|}
\hline $\begin{array}{l}\text { Palaeo } \\
\text { (Millennia) }\end{array}$ & $\begin{array}{l}\text { - Sedimentology } \\
\text { - Stratigraphy } \\
\text { - Dating: Radiocarbon, OSL, tree } \\
\text { rings }\end{array}$ & $\begin{array}{l}\text { - Insight into the underlying processes } \\
\text { - Provides accurate dating. Well constrained } \\
\text { layers can be dated to decadal or even } \\
\text { annual resolution }\end{array}$ & $\begin{array}{l}\text { - Requires specialist knowledge } \\
\text { - Dating using OSL and radiocarbon is } \\
\text { expensive }\end{array}$ \\
\hline
\end{tabular}


Table 3 The minimum spatial and spectral requirements for satellite data and minimum photographic scale for aerial photograph for identification of land cover and attributes 23, 26.

\begin{tabular}{|c|c|c|c|c|}
\hline $\begin{array}{l}\text { Land cover/use } \\
\text { attributes (USGS } \\
\text { levels) }\end{array}$ & $\begin{array}{l}\text { Minimum spatial } \\
\text { resolution required } \\
\text { for identification } \\
\text { from satellite data }\end{array}$ & $\begin{array}{l}\text { Spectral } \\
\text { requirements }^{+}\end{array}$ & Data sources & $\begin{array}{l}\text { Minimum scale } \\
\text { required if aerial } \\
\text { photos are used as the } \\
\text { main data source }\end{array}$ \\
\hline Land cover (I) & $20 \mathrm{~m}-1 \mathrm{~km}$ & VIS, IR, Radar & $\begin{array}{l}\text { MODIS } \\
\text { Orbview-1 } \\
\text { NOAA AVHRR } \\
\text { Landsat MSS } \\
\text { EnviSat-1 (MERIS) }\end{array}$ & $1: 40,000$ \\
\hline Cover types (II) & $10-100 m$ & VIS, IR, Radar & $\begin{array}{l}\text { Landsat TM 4-7 } \\
\text { Landsat ETM } 7 \\
\text { IRS (XS) } \\
\text { ASTER } \\
\text { RADARSAT }\end{array}$ & $1: 20,000$ \\
\hline $\begin{array}{l}\text { Species dominance } \\
\text { (III) }\end{array}$ & $1-30 m$ & $\begin{array}{l}\text { VIS, IR, } \\
\text { Panchromatic }\end{array}$ & $\begin{array}{l}\text { IKONOS } \\
\text { Spot } 5 \\
\text { Quickbird }\end{array}$ & $1: 10,000$ \\
\hline $\begin{array}{l}\text { Species } \\
\text { identification (IV) }\end{array}$ & $0.1-2 m$ & Panchromatic & $\begin{array}{l}\text { GeoEye-1 } \\
\text { WorldView-1 } \\
\text { OrbView-3 } \\
\text { LiDAR }\end{array}$ & $1: 2400-1: 1200$ \\
\hline
\end{tabular}

+ Spectral bandwidths: VIS, visible (red, green, blue); IR, near- and middle- infrared; Radar, microwave; Panchromatic, greyscale images sensitive to the visible and ultraviolet spectra. 
Further Reading/Resources

REFORM (Restoring rivers for effective river management) website and wiki, www.reformrivers.eu, wiki.reformrivers.eu. 